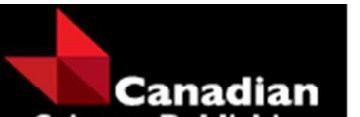

Science Publishing

Canadian Journal of Forest Research

Revue canadienne de recherche forestière

\title{
Comparative growth trends of five northern hardwood and montane tree species reveal divergent trajectories and response to climate
}

\begin{tabular}{|r|l|}
\hline Journal: & Canadian Journal of Forest Research \\
\hline Manuscript ID & cjfr-2016-0308.R2 \\
\hline Manuscript Type: & Article \\
\hline Date Submitted by the Author: & 06-Feb-2017 \\
\hline Complete List of Authors: & $\begin{array}{l}\text { Kosiba, Alexandra; University of Vermont, Rubenstein School of } \\
\text { Enviornment and Natural Resources } \\
\text { Schaberg, Paul; USDA Forest Service } \\
\text { Rayback, Shelly; University of Vermont, Geography } \\
\text { Hawley, Gary; University of Vermont, Rubenstein School of Enviornment } \\
\text { and Natural Resources }\end{array}$ \\
\hline $\begin{array}{r}\text { Keyword: } \\
\text { Is the invited manuscript for } \\
\text { consideration in a Special } \\
\text { Issue? : }\end{array}$ & \\
\hline
\end{tabular}

\section{SCHOLARONE ${ }^{m}$ \\ Manuscripts}


1 Comparative growth trends of five northern hardwood and montane tree species reveal 2 divergent trajectories and response to climate

3

4

5

6

${ }^{a}$ The University of Vermont, Rubenstein School of Environment and Natural Resources, Burlington, VT 05405, USA, p: +1 (802) 656-2911, f: +1 (802)656-8683, akosiba@uvm.edu, ghawley@uvm.edu

$13{ }^{\mathrm{b}}$ Forest Service, U.S. Department of Agriculture, Northern Research Station, Burlington, VT 14 05405, USA, p: +1 (802) 656-1715, f: +1 (802) 656-8683, pschaberg@ff.fed.us

$15{ }^{\mathrm{c}}$ The University of Vermont, Department of Geography, Burlington, VT 05405, USA, p: +1 16 (802) 656-3019, f: +1 (802)656-3042, srayback@uvm.edu

17

$18 \quad{ }^{*}$ Corresponding author. E-mail address: akosiba@uvm.edu (A.M. Kosiba). 
19 Abstract: In the northeastern US, tree declines associated with acid deposition-induced calcium depletion have been documented, notably for red spruce (Picea rubens Sarg.) and sugar maple (Acer saccharum Marsh.). There is conflicting evidence if co-occurring tree species have capitalized on these declines or suffered similar growth reductions; and, how growth has fluctuated relative to environmental variables. We examined five species along three elevational transects on Mt. Mansfield, Vermont: sugar maple, red spruce, red maple (Acer rubrum L.), yellow birch (Betula alleghaniensis, Britton), and balsam fir (Abies balsamea, [L.] Mill.). We found baseline differences in growth. Red maple and yellow birch had the highest growth, sugar maple and red spruce intermediate, and balsam fir the lowest. While some of year-to-year declines were associated with specific stress events, protracted patterns, such as recent increases in red spruce and red maple growth, were correlated with increased temperature and cooling degree days (heat index). For most species and elevations, there was a positive association between temperature and growth, but a negative association with growth the following year. Based on our comparisons, for some species growth at Mt. Mansfield aligns with regional trends and suggests that patterns assessed here may be indicative of the broader region. 


\section{Introduction}

37 Regional forests in the northeastern United States (US) reflect temporally and

38 spatially complex land use change in the $19^{\text {th }}$ and $20^{\text {th }}$ centuries that included

39 deforestation, agricultural expansion, and subsequent reforestation (Whitney 1994).

40 Resulting second growth forests were then subjected to novel anthropogenic stress in the

$4120^{\text {th }}$ century - notably acid deposition-induced nutrient perturbations that altered forest

42 health and productivity (DeHayes et al. 1999; Greaver et al. 2012). In particular, acidic

43 deposition and resulting calcium (Ca) depletion have been associated with health and

44 productivity declines for red spruce (Picea rubens Sarg.) (DeHayes et al. 1999) and sugar

45 maple (Acer saccharum Marsh.) (Schaberg et al. 2006) - two dominant and economically

46 important tree species in the northeastern US. Added to the stress of pollutants and

47 decades of soil cation depletion, anthropogenic emissions of carbon dioxide $\left(\mathrm{CO}_{2}\right)$ and

48 other greenhouse gases have induced changes in the global climate. Greenhouse gas

49 accumulations have led to an increase in the annual mean temperatures in the

50 northeastern US of $0.09^{\circ} \mathrm{C}$ decade $^{-1}$ (1895-2011), resulting in a lengthening of the freeze-

51 free period and functional growing season (Kunkel et al. 2013). While precipitation has

52 not significantly changed for winter, spring, or summer, fall and annual precipitation

53 totals have increased 0.61 and $0.99 \mathrm{~cm} \mathrm{decade}^{-1}$, respectively (Kunkel et al. 2013).

54 Continued changes in temperature and precipitation, alone and in combination with other

55 stressors, could push trees beyond the environmental thresholds to which they are

56 adapted and result in reduced competitive capacity, growth, and survival for some species

57 compared to others. 
Whereas the declines of several tree species associated with acid deposition are

59 well documented in the region, research suggests that some of these chronically stressed

60 species are experiencing contemporary growth increases (Kosiba et al. 2013) and possible

61 range expansion (Beckage et al. 2008; Foster and D'Amato 2015). Both deviations are

62 hypothesized to be associated with changes in environmental factors, such as elevated

63 atmospheric $\mathrm{CO}_{2}$ concentrations, fluctuating atmospheric pollution, and rising

64 temperature. Elevated $\mathrm{CO}_{2}$ has been proposed to cause a fertilization effect in some trees

65 (Salzer et al. 2009; Soule and Knapp 2006), but other findings have not supported this

66 (Bader et al. 2013; Girardin et al. 2016; Körner et al. 2005). While acid deposition

67 initially caused declines in some tree species, the enforcement of the Clean Air Act and

68 subsequent amendments has reduced sulfur (S) and, less dramatically, nitrogen (N)

69 deposition (Burns et al. 2011). Removal of this source of damage could allow for a

70 recovery for chronically stressed species and, further, $\mathrm{N}$ deposition can promote growth,

71 particularly in N-limited ecosystems (Aber et al. 1998). Rising temperatures could also

72 extend the functional growing season, especially for temperate conifers that retain foliage

73 year-round (Kosiba et al. 2013).

74 While anthropogenic stress continues to mount within northeastern forests, there

75 is limited evidence of clear trends in forest response; yet, large alterations in tree growth

76 rates could have profound effects on the ecology of these forests, including changes to

77 carbon (C) pools, biogeochemical and hydrological cycles, and species composition.

78 These fluctuations could alter important ecosystem services, including ones with direct

79 economic impacts, such as wood products and recreation. 
Here, we present growth patterns and trends determined using xylem annual

81 increment measurements for five tree species that characterize the northern hardwood and

82 montane spruce-fir forests: sugar maple, red spruce, red maple (Acer rubrum L.), yellow

83 birch (Betula alleghaniensis, Britton), and balsam fir (Abies balsamea, [L.] Mill.)

84 growing along elevational transects on Vermont's tallest mountain: Mt. Mansfield. We

85 hypothesized that trees would have different growth rates dependent on species,

86 elevation, and year, with some species displaying muted growth in recent decades. We

87 expected that sugar maple, a species that has experienced geographically broad decline

88 since the 1980s (Horsley et al. 2002), and yellow birch, a species with limited reports of

89 decline (van Doorn et al. 2011), would have reduced recent growth. Conversely, we

90 predicted that red spruce at Mt. Mansfield would show recent increases in growth

91 synchronous with a regional growth pattern of unknown cause (Kosiba et al., 2013). We

92 expected that sympatric balsam fir may have experienced competitive reductions in

93 growth concurrent with increases in red spruce growth. Although red maple stocking and

94 growth in the understory has increased regionally (Abrams 1998), growth trends for

95 dominant and co-dominant red maple are unresolved.

96 By associating the nature and timing of observed growth relative to local weather

97 and pollution data, we assessed how putative environmental drivers may have influenced

98 species growth and productivity over time. Specifically, we anticipated that deposition of

$99 \mathrm{~S}$ and $\mathrm{N}$ would be negatively associated with red spruce and sugar maple growth,

100 particularly in the 1970s-90s when deposition was the greatest. We hypothesized that

101 atmospheric $\mathrm{CO}_{2}$ concentration, summer temperature, and growing season length would

102 be positively associated with growth and that temperature relationships would strengthen 
103 with increasing elevation. We expected that increased fall and spring temperatures would

104 be beneficial to evergreen conifers, as they can photosynthesize outside the traditional

105 growing season when sympatric deciduous trees are leafless. We also predicted that

106 metrics of precipitation would have a variable association with tree growth at Mt.

107 Mansfield considering that these trees persisted through severe droughts in the 1930s and

108 60s (Dupigny-Giroux 2002) as well as a current pluvial (Pederson et al. 2013).

109

\section{Methods}

\section{Site description}

112 Mt. Mansfield State Forest, part of the northern Appalachian mountain chain,

113 located in north-central VT (Underhill, VT, USA; $44.5439^{\circ} \mathrm{N}, 72.8143^{\circ} \mathrm{W}$ ), is a 18000

114 hectare parcel comprised of multiple forest types across an altitudinal range of

115 approximately $1000 \mathrm{~m}$, with a summit at $1339 \mathrm{~m}$. A northern hardwood forest,

116 dominated by sugar and red maple, American beech (Fagus grandifolia Ehrh.), and

117 yellow birch, extends to $\sim 800 \mathrm{~m}$, where it merges in a transition zone with a montane

118 spruce-fir forest, primarily composed of balsam fir and red spruce. Red spruce, a

119 temperate conifer, is frequently found intermixed in the northern hardwood ecotone. The

120 dynamics of the forests are controlled by localized wind events and individual tree

121 mortality; however, historical timber harvest occurred sporadically in the early $20^{\text {th }}$

122 century through parts of the Mt. Mansfield State Forest (Cogbill 1996). Soils are

123 primarily stony podzols with considerable areas of rock outcrops, particularly

124 approaching the summit (Soil Survey Staff 2015). 
The climate of Mt. Mansfield State Forest is continental, encompassing a large

126 temperature range (Fig. S1) and is affected by its proximal location to Lake Champlain, a

127126910 hectare lake $24 \mathrm{~km}$ west of the study site, which moderates temperature and

128 increases snow fall amounts. The annual mean temperature is $4.2^{\circ} \mathrm{C}$ with an average of

$129154.6 \mathrm{~cm}$ of precipitation deposited uniformly throughout the year (Fig. S1) (PRISM

130 Climate Group 2004). January is the coldest month and July is the warmest $\left(-10.5^{\circ} \mathrm{C}\right.$ and

$131 \quad 17.6^{\circ} \mathrm{C}$ average temperature $1925-2012$ for study location, respectively) (PRISM Climate

132 Group 2004). Continuous snow cover is the winter norm, persisting over 5 months at

133 higher elevations. Humidity and water availability increase with elevation.

\section{Plot selection}

136 Elevational transects were set up in three of the four watersheds on Mt. Mansfield

137 (Brown's River, Stevensville Brook, and Ranch Brook Watersheds). No transect was

138 established in the fourth watershed because this area has experienced anthropogenic

139 disturbance associated with a commercial ski area. Along each transect, three plots were

140 selected - one within each of the following elevational zones: low (450-650 m a.s.1.), mid

141 (750-850 m) and high (900-1000 m) $(n$ plots = 9, Fig. 1), which align with northern

142 hardwoods, transition, and montane spruce-fir ecotones. No obvious stand mortality or

143 substantial recent disturbance was evident in any of the plots.

144 Plots contained 10-14 dominant or co-dominant trees of each of the target tree

145 species equally distributed around plot center to avoid differing competition pressures

146 among trees. Trees with obvious bole or crown damage or those growing in anomalous

147 conditions were not selected. We sampled red maple, sugar maple, and red spruce at low 
148 elevation; sugar maple, yellow birch, and red spruce at mid elevation; and red spruce and

149 balsam fir at high elevation (Fig. 1). Due to differential species densities across the

150 landscape and different number of species sampled per plot, plots were of variable radius

151 (approx. 20-35 m).

152 We selected species if they were the dominant components of the montane

153 spruce-fir (red spruce and balsam fir) or northern hardwood (sugar maple and yellow

154 birch) forests, or if the species has experienced increased dominance in this latter forest

155 type (red maple; Abrams 1998). A dominant component of the northern hardwood forest,

156 American beech, was not assessed because its growth dynamics have been altered

157 following widespread damage from the beech bark disease complex (Gavin and Peart

158 1993).

\section{Dendrochronology}

161 We increment cored selected trees $(n=256)$ following standard

162 dendrochronological techniques (Stokes and Smiley 1968) in the fall of 2012. We

163 collected two $5 \mathrm{~mm}$ increment cores per tree at stem DBH (diameter at breast height, 1.37

$164 \mathrm{~m}$ above ground level) at $180^{\circ}$ and perpendicular to the slope. Cores were air-dried,

165 sanded with progressively finer grit sandpaper (ranging from 100-1500 grit dependent on

166 species) and visually crossdated using the list method (Yamaguchi 1991). We

167 microscopically measured rings to $0.001 \mathrm{~mm}$ resolution using a Velmex sliding stage unit

168 with MeasureJ2X software (VoorTech Consulting, Holderness, NH) and used the

169 computer program COFECHA to detect and correct for potential crossdating errors in

170 ring series (Holmes 1983). Individual cores were discarded if they were poorly correlated 
171 with the master chronology (i.e., below Pearson critical correlation level of 0.328 [99\%

$172 \mathrm{CL}]$ ). For descriptive purposes, tree age (at breast height) was calculated using the

173 maximum number of rings per tree if pith was evident or was estimated per core using a

174 pith indicator (Speer 2010) if pith was not reached. For all trees, we were able to estimate

175 age from at least one core.

176 For the climate analyses, we detrended, standardized, and prewhitened all raw

177 ring width series and computed biweight robust mean chronologies per species per

178 elevation. Descriptive statistics (sample sizes, R bar, EPS [expressed population signal]

179 and SNR [signal:noise]) of resulting chronologies were calculated using a running 30-

180 year window with 15-year overlap using Spearman correlation coefficients (Table S1)

181 and used to select the best detrending and standardization technique. For all series

182 chronologies, a 67\% cubic smoothing spline (CSS) (dplR package in R), using a

183 frequency response cutoff of 0.5 was used. If this spline was a poor fit, a more

184 conservative horizontal line was fit to the data. Traditionally, chronologies are truncated

185 at the year when the EPS value falls below 0.85 (Speer 2010), but this would preclude the

186 use of a portion of both the red maple and sugar maple chronologies at low elevations due

187 to their young age and comparatively small sample size. Because results here were solely

188 used to investigate growth-climate or -deposition relationships rather than for climatic

189 reconstructions, we reduced the threshold to 0.80 , allowing for the use of a common

190 period spanning from 1925-2012. However, lower EPS values indicate that these trees

191 have a weaker stand-wide signal and may be more influenced by micro-site factors,

192 which could mask a cohesive stand-wide signal. Summary statistics and data on the nine

193 plots and resulting chronologies can be found summarized by species and elevational 
194 zone in Table S2. Comparisons of growth among species and elevations was done with

195 Kruskal-Wallis rank sums test followed by the Wilcoxon method for pairwise

196 comparisons, as data did not meet the assumptions of equal variance $(P \leq 0.05)$.

197 We also averaged raw ring widths by tree and converted measurements into basal

198 area increment (BAI, $\mathrm{cm}^{2}$ year ${ }^{-1}$ ) assuming a circular outline of stem cross sections (Cook

199 and Kairiukstis 1990) and accounting for bark thickness. BAI is considered a more

200 meaningful indicator of tree growth from a physiological standpoint because it provides

201 an indication of annual stemwood production while accounting for the effects of stem

202 geometry on radial growth associated with tree-maturation (Hornbeck and Smith 1985;

203 LeBlanc 1992; West 1980). We then computed biweight robust mean BAI chronologies

204 per species per elevation using the dplR package (Bunn et al. 2015) for R (Version 3.1.1)

205 (R Development Core Team 2015) to moderate the effect of large BAI values and/or

206 outliers on the mean chronology.

207

208 Growth associated with climate, deposition

209 Climate data (maximum and minimum monthly temperature $\left[\mathrm{T}_{\min }, \mathrm{T}_{\max }\right]$ and total

210 monthly precipitation [P]) from 1925-2012 were obtained from the PRISM Climate

211 Group (PRISM Climate Group 2004). To reduce the number of variables assessed and

212 limit the occurrence of type II errors, we computed seasonal mean ( $\left.\mathrm{T}_{\text {mean }}\right)$, maximum, and

213 minimum temperatures (Winter: previous December-February, Spring: March-May,

214 Summer: June-August, Fall: September-November), annual water year (previous [p]

215 October to current September) mean temperature, and seasonal and water year

216 precipitation totals. Using monthly data, we also calculated the average temperature for 
217 an extended growing season (May-August and June-September) (Fig. S1).

218 Pollutant S and N deposition data by water year were obtained from the Hubbard

219 Brook Experimental Forest (HBEF; Watershed 1), Thorton, NH, USA, spanning $1965-$

2202010 (Likens 2010) (Fig. S1). As this dataset covers more years than the one from Mt.

221 Mansfield (1984-2012) (National Atmospheric Deposition Program 2014) and the

222 datasets were highly correlated $(\mathrm{R}=0.94, P<0.0001)$, we combined them by adjusting

223 HBEF data via regression analysis and then added this to the Mt. Mansfield dataset for

224 continuous coverage from 1965-2012. We gathered data of annual atmospheric $\mathrm{CO}_{2}$

225 concentration from Mauna Loa Observatory, HI, USA (NOAA Earth System Research

226 Laboratory Global Monitoring Division 2013) and from Law Dome, Antarctica ice core

227 data (World Data Center for Paleoclimatology and NOAA Paleoclimatology Program);

228 combined for a $\mathrm{CO}_{2}$ dataset spanning 1925-2012. We also collected the following data:

229 Vermont Palmer Drought Severity Index (PDSI) (National Drought Mitigation Center

230 2014), and three measures of degree days: growing degree days (GDD, measured as

231 cumulative degrees $\left.>5^{\circ} \mathrm{C}\left[41^{\circ} \mathrm{F}\right]\right)$, cooling degree days $\left(\mathrm{CDD},>18.3^{\circ} \mathrm{C}\left[65^{\circ} \mathrm{F}\right]\right)$ and

232 heating degree days $\left.\left(\mathrm{HDD},<18.3^{\circ} \mathrm{C}\left[65^{\circ} \mathrm{F}\right]\right)\right)$ for Burlington International Airport, VT

233 (NOAA National Weather Serivce 2014), and monthly Standardized Precipitation-

234 Evapotranspiration Index (SPEI, 1-month) for VT, a multi-scalar drought and

235 temperature index that includes the effects of evapotranspiration (The National Drought

236 Mitigation Center 2012). These datasets were chosen based on proximity or length of

237 record; these datasets covered 1945-2012 (Fig. S1).

238 Growth relationships with climate, deposition, and other data were assessed using

239 treeclim (Zang and Biondi 2015) for R. Treeclim uses time-dependent bootstrapped 
240 resampling (1000 iterations) to test for linear correlations between the residual ring width

241 data and each subvector of the climate matrix (Zang and Biondi 2015). To investigate the

242 dominant drivers of tree growth, we first examined stationary correlations over the

243 common period (or a limited subset for climate/deposition datasets spanning fewer

244 years), including previous year's climate and deposition on current year's growth,.

245 Second, to assess the temporal stability of climate-growth relationships, we used the

246 significant variables from the first analysis to evaluate relationships with growth per

247 temporal quartile. Third, we used principal component analysis to examine common

248 modes of growth among species per elevation. Using the first principle component (PC)

249 per elevation, we again examined stationary correlations with our climate and deposition

250 variables. For all analyses, Spearman correlation coefficients were computed with a $99 \%$

251 CI to reduce the number of input variables, type II errors, and covariation among 252 variables.

253 Lastly, we used the significant climate and pollution deposition variables from the

254 first analysis to model growth per species and elevation. All variables were first

255 standardized $(\mu=0, \sigma=1)$. If multicollinearity was evident among variables, we used

256 forward stepwise linear regression (using AIC criteria) to reduce selected variables. For

257 all species and elevation pairs, we then created linear models to best explain growth; non-

258 significant variables were removed and the model was reassessed. Using the residuals of

259 these models, we then regressed $\mathrm{CO}_{2}$ data to examine if, after accounting for the

260 dominant climate effects, there was a detectable $\mathrm{CO}_{2}$ affect (Girardin et al. 2016).

262 Comparisons with other chronologies and datasets 
We used other crossdated ( \pm 0 yrs.) tree ring chronologies collected by the authors

264 or affiliates (Engel et al. 2016; Hansen 2015; Weverka 2012) to compare growth trends

265 on Mt. Mansfield to other locations in the region using Pearson Product-Moment

266 Correlation. All chronologies were collected following similar methods described above

267 and converted into BAI. Due to age limits of the chronologies from the HBEF, we

268 constrained analyses to 1950-2012 for sugar maple and yellow birch (Hansen 2015).

\section{$270 \quad$ Results}

\section{Absolute growth}

We found significant and consistent growth differences among the species $(P<$

273 0.001) (Fig. 2A). Yellow birch and red maple had the largest mean growth (mean BAI \pm

274 SD: $15.2 \pm 5.1$ and $13.0 \pm 4.3 \mathrm{~cm}^{2}$, respectively). Sugar maple and red spruce were

275 intermediate in growth $\left(7.1 \pm 2.0\right.$ and $7.7 \pm 2.9 \mathrm{~cm}^{2}$, respectively) and balsam fir had the

276 lowest growth $\left(4.7 \pm 2.4 \mathrm{~cm}^{2}\right)$. These patterns were fairly stable over the quartiles of the

277 chronology, excluding the first quartile (1925-1946) and the most recent growth (2002-

278 2012).

279 Growth was consistently higher at low and mid elevations compared with high

280 elevation (Fig. 2B) $(P<0.001)$. For the chronology overall and for the central two

281 quartiles (1947-1968, 1969-1990), growth was greater at mid elevations than low

282 elevation. For all three elevations, overall growth increases in the most recent decade

283 were driven by increases in two species: red spruce and red maple.

284 For the two species sampled at multiple elevations (sugar maple and red spruce),

285 species-specific growth across elevations showed differing patterns (Fig. 3). Sugar maple 
286 at low elevation had significantly higher mean growth than at mid elevation $(8.1 \pm 2.6$

287 and $6.5 \pm 1.7 \mathrm{~cm}^{2}$, respectively; $P<0.01$ ), juxtaposing the general patterns that mid

288 elevation plots had higher mean BAI overall. For both elevations, sugar maple maximum

289 growth was only slightly higher than the mean and occurred in the third quartile: 1985-95

290 for low elevation and 1970-90 for mid elevation trees. Following this peak, both

291 chronologies exhibited slight declines in growth. Mid elevation red spruce had the

292 highest average growth $\left(13.0 \pm 4.3 \mathrm{~cm}^{2}\right)$, with low elevation intermediate $\left(7.8 \pm 3.1 \mathrm{~cm}^{2}\right)$,

293 and high elevation the lowest $\left(4.1 \pm 3.2 \mathrm{~cm}^{2}\right)($ Fig. 3$)(P<0.01)$. For red spruce at all

294 elevations, maximum growth occurred in 2012 (year of sampling), and was considerably

295 higher than overall chronology means. At both mid and high elevations, four out of five

296 years of maximum red spruce growth occurred in the years immediately prior to sampling $297 \quad(2009-12)$.

299 Growth trends

300 Species-to-species comparisons per elevation (Fig. 3) reveal that peak growth

301 varied, but for all species, the highest growth years were in the second half of the

302 chronology (e.g., 1960s to 2012). At low elevation, both red spruce and red maple

303 displayed recent increases in growth, while sugar maple did not. For all three species at

304 low elevation, peak growth roughly coincided; although for both red maple and red

305 spruce, maximum growth persisted longer and was more recent than for sugar maple. At

306 mid elevation, highest growth for yellow birch and sugar maple corresponded (1960s-

307 80s), yet red spruce peak growth occurred when these neighboring species were showing 
308 decreases. At high elevation, balsam fir experienced maximum growth at the end of the

309 1980s through the early 2000s.

310 The recent growth surge of red spruce was not seen in the other species at mid

311 elevation. While this increase was most pronounced for low and mid elevation red

312 spruce, red spruce growing at high elevation, where growth over the length of the

313 chronology was more stable and constrained compared to lower elevation red spruce, also

314 exhibit this upward trend. At all elevations, red spruce exhibited periods of depressed

315 growth beginning in the mid-twentieth century that align with suspected or known winter

316 injury events (Johnson et al. 1986; Lazarus et al. 2004).

318 Climate and deposition relationships with growth

319 Examining climate-growth relationships using the principal components (PCs)

320 derived from chronologies per elevation, we saw that overall, all three elevations display

321 a positive correlation between growth and growing season temperature $(P<0.01$, Table

322 1). At low elevation, Summer $T_{\text {mean }}$ was best associated with growth $(\rho=0.38)$, along

323 with $\mathrm{NH}_{4}{ }^{+}$deposition $(\rho=0.35)$. Both mid and high elevations showed positive

324 correlations with CDD and growing season temperatures (e.g., Spring, Summer $\mathrm{T}_{\text {mean }}$ ).

325 However, non-growing season temperatures and PDSI were important to high elevation

326 trees only. A model of growth at both mid and high elevations identified CDD as the best

327 predictor $\left(\mathrm{R}^{2}\right.$ adj $=0.13, P=0.001$ and $\mathrm{R}_{\text {adj }}^{2}=0.10, P=0.04$, respectively $)$. At low

328 elevation, the growth model included a positive effect of May-Aug $\mathrm{T}_{\text {mean }}\left(\mathrm{R}^{2}{ }_{\text {adj }}=0.08, P\right.$

$329=0.005)$. Atmospheric $\mathrm{CO}_{2}$ concentration was not significantly associated with growth 
330 for any of the species or elevations using either growth, PCs by elevation, or residuals

331 (not shown).

332 At high elevation, balsam fir growth was positively correlated with temperature

$333(P<0.01$; Table 2$)$. The strongest positive correlations occurred with previous year's $(\mathrm{p})$

334 Fall $T_{\min }(\rho=0.38)$ and Spring $T_{\min }(\rho=0.24)$, while there was a negative association

335 with $\operatorname{pCDD}(\rho=-0.37)$ and $\operatorname{pGDD}(\rho=-0.31)$ (Table 2$)$. Although significant overall $(P$

$336<0.01)$, the strength of the relationships between balsam fir growth and other variables

337 declined in the middle of the chronology (1969-1990). The best model to predict balsam

338 fir growth $\left(\mathrm{R}^{2}\right.$ adj $\left.=0.19, P=0.0008\right)$ included a negative effect of $\mathrm{pCDD}\left(\mathrm{R}^{2}\right.$ adj $=0.13$,

$339 P=0.002)$ and a positive effect of Spring $\mathrm{T}_{\min }\left(\mathrm{R}_{\text {adj }}^{2}=0.05, P=0.04\right)$.

340 Red spruce exhibited the strongest positive relationships $(P<0.01)$ with

341 temperature (CDD, GDD, and water year $\left.\mathrm{T}_{\text {mean }}\right)$, including a strong correlation with non-

342 growing season temperature (Table 2). Indeed, water year $\mathrm{T}_{\text {mean }}$ was positively associated

343 with red spruce growth at all elevations and while not always significant, displayed a

344 consistently positive correlation with growth across quartiles. Like the other species,

345 pCDD was strongly, negatively correlated to red spruce growth, and this pattern persisted

346 through time $(P<0.01)$. At both mid and high elevations, there was a positive association

347 between growth and pWinter $T_{\max }(\rho=0.27$ and 0.23 , respectively). This relationship

348 was negative in the third quartile, 1969-1990. Interestingly, $\mathrm{pNO}_{3}$ deposition was

349 negatively associated with growth of red spruce at low elevation $(P<0.01, \rho=-0.37)$,

350 which strengthened through the quartiles of the chronology.

351 For red spruce at low elevation, we found that the negative effects of both HDD

$352 \quad\left(\mathrm{R}^{2}\right.$ adj $\left.=0.11, P<0.0001\right)$ and $\mathrm{pCDD}\left(\mathrm{R}^{2}\right.$ adj $\left.=0.15, P<0.0001\right)$ were the best predictors of 
353 growth in a linear model $\left(\mathrm{R}_{\text {adj }}^{2}=0.40, P>0.0001\right)$. At mid elevation, the best model $\left(\mathrm{R}^{2}\right.$ adj

$354=0.31, P<0.0001)$ included a positive effect of water year $\mathrm{T}_{\text {mean }}\left(\mathrm{R}_{\text {adj }}^{2}=0.13, P=0.0006\right)$

355 and, like low elevation, a negative effect of $\mathrm{pCDD}\left(\mathrm{R}_{\text {adj }}^{2}=0.12, P=0.0002\right)$. At high

356 elevation, the best model included a negative effect of both $\mathrm{pCDD}\left(\mathrm{R}^{2}{ }_{\text {adj }}=0.09, P=\right.$

$3570.0001)$ and $\operatorname{HDD}\left(\mathrm{R}^{2}{ }_{\text {adj }}=0.11, P=0.018\right)$, and a positive effect of GDD $\left(\mathrm{R}^{2}{ }_{\text {adj }}=0.19, P\right.$

$358=0.017)\left(\right.$ overall model $\mathrm{R}^{2}$ adj $\left.=0.35, P<0.0001\right)$.

359 Measures of degree-days and temperature were also important for red maple at

360 low elevation $(P<0.01)$ (Table 2). Growing season temperature (i.e., Summer $\mathrm{T}_{\text {mean, }}$

361 June-September $\mathrm{T}_{\text {mean }}$, and CDD) was positively correlated with red maple growth $(P<$

$3620.01, \rho=0.30,0.26$, and 0.39 , respectively), while preceding year's heat accumulation

363 (pCDD) was negatively associated $(\rho=-0.34)$. For red maple, the best growth model

$364\left(\mathrm{R}^{2}\right.$ adj $\left.=0.20, P=0.0004\right)$ included a negative effect of $\mathrm{pCDD}\left(\mathrm{R}_{\text {adj }}^{2}=0.11, P=0.002\right)$

365 and a positive effect of Summer $\mathrm{T}_{\text {mean }}\left(\mathrm{R}^{2}{ }_{\text {adj }}=0.08, P=0.006\right)$.

366 At low elevation, sugar maple growth was not correlated $(P>0.01)$ with the

367 selected variables (Table 2); therefore, we were unable to create a model of growth. For

368 sugar maple at mid elevation, Summer $\mathrm{T}_{\text {mean }}$ was positively associated with growth $(P<$

$3690.01, \rho=0.26)$. However, this relationship was not consistent through the quartiles. Like

370 many of the other species in this study, growth for these trees also exhibited a negative

371 correlation $(P<0.01)$ with pSummer $\mathrm{T}_{\text {mean }}(\rho=-0.25)$ and $p \operatorname{Summer} \mathrm{T}_{\max }(\rho=-0.27)$, as

372 well as with pCDD $(\rho=-0.38)$. To model growth, we were limited by the number of and

373 high collinearity of input variables. Both $\mathrm{pSummer} \mathrm{T}_{\text {mean }}$ and $\mathrm{pSummer} \mathrm{T}_{\max }$ explained a

374 similar amount of growth variation when fit separately $\left(\mathrm{R}^{2}\right.$ adj $=0.06, P=0.01$ for both $)$. 
We did not find any negative correlations between yellow birch growth and the

376 variables selected (Table 2). Yellow birch, however, did display positive associations

377 with summer $\mathrm{T}_{\text {mean }}(P<0.01, \rho=0.29)$ and these trends were consistent through the

378 quartiles of the chronology. However, when we modeled growth using Summer $\mathrm{T}_{\text {mean }}$,

379 only a small amount of growth variation was explained $\left(\mathrm{R}_{\text {adj }}^{2}=0.07, P=0.008\right)$

381 Comparisons with other chronologies

382 We compared red spruce growth from this study with red spruce from a wide 383 range of plots in VT, New Hampshire, and Massachusetts ( $n$ trees $=452)$ collected in

384 2010, 2011, and 2012 (Engel et al. 2016; Kosiba et al. 2013; Weverka 2012). The

385 chronologies were significantly correlated $(\mathrm{R}=0.92, P<0.0001$; Fig. 4A). We also

386 compared sugar maple and yellow birch from this study to those species from the HBEF

387 collected in 2012 (Hansen 2015). For sugar maple ( $n$ trees $\mathrm{HBEF}=163$; Fig. 4B) the

388 chronologies were significantly correlated $(\mathrm{R}=0.57, P<0.0001)$, but for yellow birch $(n$

389 trees $\mathrm{HBEF}=170$; Fig. 4C) they were not $(\mathrm{R}=-0.19, P=0.13)$.

390

\section{Discussion}

\section{Patterns of growth}

393 Significant and consistent growth differences among the species highlight their

394 divergent silvics (Burns and Honkala 1990). Yellow birch and red maple, which are

395 intermediate in shade tolerance with moderately high growth potentials (Burns and

396 Honkala 1990), had the greatest mean growth. Sugar maple and red spruce, which are

397 both shade tolerant with the ability to display higher growth when a mature component of 
398 the canopy (Burns and Honkala 1990), were intermediate in growth, while balsam fir,

399 highly shade tolerant and with the potential for constrained growth with elevated stocking

400 (Burns and Honkala 1990), displayed the lowest growth. Species-to-species comparisons

401 per elevation reveal that peak growth varied over time, but for all species, the highest

402 growth years occurred in the second half of the chronology.

403 Lower growth and more muted disparities among the species in the first quartile

404 of the chronology may signify that competition during stand maturation was a strong

405 constraint on growth. Historical anthropogenic land clearing has left a legacy on the

406 forests of Mt. Mansfield evident in the ages of sample trees (Table S1). In the absence of

407 a substantial natural disturbance, it is likely that selective logging has resulted in the age

408 divergence among the species and elevations. Cogbill (1996) outlined several logging

409 events in the Stevensville Brook Watershed on the western flank of Mt. Mansfield, and it

410 is suspected that widespread harvesting occurred in the other watersheds as well.

411 Assessment of stand dynamics (data not shown) confirmed that release events were

412 stochastic and not consistent within or among plots.

413 Some of the year-to-year variations in growth (Fig. 3) can be attributed to known

414 biotic and abiotic stressors. For example, specific low growth years for sugar maple are

415 likely associated with the 1993 infestation of pear thrips (Taeniothrips inconsequens

416 [Uzel]) and a late spring frost in 2010 (Hufkens et al. 2012; Vermont Agency of Natural

417 Resources Department of Forest Parks \& Recreation 2010). While this late frost event

418 could have affected sugar maple at low elevation, because no coincident downturn in

419 growth was evident at mid elevation (Fig. 3), we suspect that mid elevation trees were

420 unaffected due to a later timing of bud break relative to frost exposure. Additionally, a 
421 severe ice storm in 1998 that broke the limbs of many hardwood species (Rhoads et al.

422 2002), was reported for many mid and high elevation sites (Vermont Agency of Natural

423 Resources Department of Forest Parks \& Recreation 2013). Areas of high ice loading

424 align with our mid elevation zone, and when followed by a severe drought in 1999, may

425 have caused the growth declines for yellow birch and sugar maple evident in 1999

426 through 2000 (Fig. 3). Lastly, declines in growth apparent for red spruce at all elevations

427 (Fig. 3) correspond with documented winter injury events (Johnson et al. 1986),

428 including in 2003, which was a severe event across the region (Lazarus et al. 2004).

429 At high elevation, balsam fir experienced maximum growth at the end of the

430 1980s through the early 2000s (Fig. 3), which parallels the documented decline of red

431 spruce (Lazarus et al. 2004) and suggests that balsam fir was able to capitalize on the

432 resulting foliar losses and growth declines of sympatric red spruce. Balsam fir is not

433 affected by winter injury due to its extreme cold tolerance (DeHayes et al. 2001). Since

434 2003, a substantial winter injury event has not occurred in the region (Vermont Agency

435 of Natural Resources Department of Forest Parks \& Recreation 2013), which may in part,

436 explain the increase in red spruce growth relative to balsam fir. However, despite some

437 differences over time, at high elevation plots, both red spruce and balsam fir had

438 relatively low growth due to limitations in growing season length and lower annual 439 temperature.

440 We detected growth reductions for sugar maple at both low and mid elevations

441 that are temporally consistent with regional declines attributed to acid deposition-induced

442 Ca depletion combined with other stress exposures (Schaberg et al. 2006). In this study, 443 growth declines were more dramatic for sugar maple at mid elevation than at low 
444 elevation. As acid deposition is more severe with increasing elevation (Johnson and

445 Siccama 1983), mid elevation sugar maple may have suffered from Ca depletion more

446 extensively and earlier than trees at lower elevation. Indeed, other studies have indicated

447 that sugar maple at mid and high elevations display greater signs of physiological stress

448 from Ca depletion than those at low elevation (Minocha et al. 2010). Although sugar

449 maple growth measurements reported here are low compared to the other sampled

450 species, they are not atypical when compared to other dendrochronological studies in

451 eastern North America (Bishop et al. 2015; Duchesne et al. 2003; Hansen 2015; Long et

452 al. 2009).

453 Red spruce on Mt. Mansfield have experienced a recent growth increase

454 consistent with other locations (Fig. 2, 3) (Kosiba et al. 2013). This increase is especially

455 pronounced at mid elevations, which has been previously demonstrated (Kosiba et al.

456 2013). However, the other species at mid elevations did not display an analogous increase

457 in growth, discounting stand dynamics for this rapid change.

458 Regardless of species-specific growth, mid elevation plots displayed significantly

459 higher growth than low and high elevations plots. This could signify that mid elevation

460 sites provide more advantageous conditions for tree growth than either lower or higher

461 elevation (e.g., for red spruce), or it could be confounded by the fact that the fastest

462 growing species for all quartiles (yellow birch) was only sampled at mid elevations.

463 Red maple also exhibited increased growth recently. However, since this study

464 surveyed a relatively small number of red maple, and comparably few studies have

465 examined red maple growth in the region, it is difficult to assess the extent of this growth

466 surge at this time (see Silva et al. 2010; Zhang et al. 2015). Additionally, because red 
467 maple was only sampled at low elevation, we do not to know if elevation influences this

468 apparent growth increase. Limited reports on red maple have revealed that its abundance

469 increased dramatically in the $20^{\text {th }}$ century (Siccama 1971), due in part to its purported

470 niche as a "super-generalist" and large ecological amplitude, which permitted

471 competitive growth advantages at a range of site conditions (Abrams 1998).

472

473 Relationships with climate and deposition

$474 \quad$ As expected, growth associations among species and elevations had differing

475 relationships to local climate and deposition. Two general growth associations were

476 evident: (1) a positive correlation with higher temperature in the year of growth

477 (particularly for red maple and red spruce, and to a lesser extent, balsam fir, yellow birch, 478 and sugar maple) and (2) a negative correlation with excessive heat (CDD: cumulative

479 temperatures $>18.3^{\circ} \mathrm{C}$ ) during the previous year (for all species except yellow birch).

480 Positive relationships between temperature and growth imply that low temperature

481 restricted growth. Negative relationships between temperature and growth the following

482 year suggest a legacy effect of higher temperature, conceivably through limitations of C

483 or other compulsory elements. For example, higher temperature could increase

484 contemporary growth if the tree consumes $\mathrm{C}$ for immediate needs, such as increased

485 maintenance respiration, growth, or reproductive buds, rather than to store $\mathrm{C}$ to support

486 growth the next year (Rennenberg et al. 2006). Similarly, temperature-induced increases

487 in growth could result in the sequestration of other nutrients (e.g., N, Ca) that temporarily

488 become limiting and indirectly suppress growth the following year (Rennenberg et al.

489 2006). 
Using CDD in growth-climate relationships provides a readily available index of

491 integrated heat exposure that was consistently associated with growth for trees at Mt.

492 Mansfield. Measures of growing season temperatures were important for both mid and

493 low elevations, while water year temperature and $\mathrm{pFall} \mathrm{T}_{\min }$ were important at high

494 elevations. Trees at both high and mid elevations displayed a positive growth correlation

495 with CDD. By quartile, it is clear that climate-growth relationships were not steady

496 through time (Table 2). For some species and variables, associations reversed for one or

497 more quartiles, complicating our ability to predict tree responses to these variables.

498 Non-growing season temperature was important for the two conifers in this study.

499 For both balsam fir and red spruce, mild autumn temperatures can delay cold hardening,

500 which allows the foliage to remain photosynthetically active for a prolonged period.

501 Additionally, because red spruce is a temperate conifer that can photosynthesize in fall,

502 winter, and spring, provided that temperatures are moderate (Schaberg and DeHayes

503 2000), it has been hypothesized that the notable and recent increase in growth could be

504 due to climatic warming that has lengthened the functional growing season for red spruce

505 (Kosiba et al. 2013).

506 At mid elevations, there was a positive association between red spruce growth and

507 previous Winter $\mathrm{T}_{\max }$, suggesting that warmer winter temperatures could provide

508 increased growth opportunities for this species. This finding has been reported by others

509 (Cook et al. 1987; McLaughlin et al. 1987). Interestingly, this relationship was negative

510 in the third quartile, 1969-1990, a period of peak acid deposition (Greaver et al. 2012)

511 and documented red spruce decline (Hornbeck et al. 1987; Johnson et al. 1988). When

512 warm winter temperatures cause thaws, red spruce can photosynthesize while sympatric 
513 species remain dormant; however, when cold temperatures return, freezing damage can

514 ensue. This process is exacerbated by acid deposition, which reduces the cold tolerance

515 of red spruce foliage (Schaberg and DeHayes 2000).

516 Red spruce growth at the Mt. Mansfield study plots corresponds well with red

517 spruce growth region-wide, implying that growth trends in this study are not a byproduct

518 of local stand dynamics and, further, that climate- and deposition- growth relationships

519 presented here may be representative of a region-wide phenomenon. Positive associations

520 with measures of growing season length and temperature (e.g., water year $\mathrm{T}_{\text {mean, }}$ Jun-Sept

$\left.521 \mathrm{~T}_{\text {mean }}, \mathrm{GDD}, \mathrm{CDD}\right)$ allude to continued favorable growth conditions and potential range

522 expansion (e.g., Foster and D'Amato 2015) for red spruce into the future. This conclusion

523 contrasts with projected species range maps that depict red spruce range constriction in

524 the future (Iverson et al. 2008). Interestingly, the period of most divergent growth

525 between Mt. Mansfield and regional red spruce was from roughly 1980 through 2008.

526 This period was interspersed with a series of winter injury events with varied intensities

527 and legacies across the region (Lazarus et al. 2004, Kosiba et al. 2013). The higher than

528 average growth at Mt. Mansfield relative to the regional chronology may indicate that red

529 spruce on Mt. Mansfield experienced less winter injury than the regional norm. Likewise,

530 the recent synchronous increase in growth evident in the chronologies indicates that this

531 rebound is a regional phenomenon, similar to the ubiquitous decline in growth following

532 the 2003 winter injury event.

533 In contrast with the other species, sugar maple growth at low elevation was not

534 correlated with the selected variables, suggesting that they may be responding to micro-

535 site parameters not considered in this analysis (e.g., nutrient availability, stand dynamics, 
536 local soil moisture, etc.). For example, PDSI is a metric for the whole state of VT that

537 does not consider site based soil and hydrological differences that may help explain tree

538 growth. Others have also shown similar weak climate-growth relationships for sugar

539 maple in the region (e.g., Bishop et al. 2015). Sugar maple growth at mid elevations

540 exhibited a negative correlation with pSummer $\mathrm{T}_{\text {mean }}$ and $\mathrm{T}_{\max }$, indicating that elevated

541 summer temperature due to climate change (Kunkle et al. 2013) could limit sugar maple

542 growth further in the future.

543 Sugar maple at HBEF (Hansen 2015) had higher growth than those at Mt.

544 Mansfield, particularly during the first half of the chronology. After 1982, the

545 chronologies are more analogous. Sugar maple at Mt. Mansfield displayed a subdued

546 decline in growth in the 1980s, but otherwise maintained consistent, low growth. It is

547 unclear why sugar maple at HBEF had higher growth than those at Mt. Mansfield for the

548 first part of the chronology, though higher acidic loading in the west of the region (e.g.,

549 Ollinger et al. 1993) could have stressed sugar maple trees there first. However, the near-

550 steady growth of sugar maple at Mt. Mansfield since 1950 (Fig. 2) seems inconsistent

551 with the possibility of early stress from acidic inputs. Another possibility is that Mt.

552 Mansfield is a more marginal site for sugar maple growth, so baseline growth there was

553 consistently lower.

554 Growth of Mt. Mansfield yellow birch did not correspond well to yellow birch

555 growing at HBEF (Hansen 2015). One possible explanation for this could be the lower

556 sample size for yellow birch ( $n=34$ trees) relative to sugar maple $(n=63$ trees $)$ at Mt.

557 Mansfield, which could reduce the accuracy of yearly growth mean estimates and 
558 increase the variation around those means. These results demonstrate the importance of

559 having high replication when looking at region-wide patterns in tree cores.

560 Surprisingly, annual S and N deposition only related to poor growth for red spruce

561 at low elevation, but not at mid and high elevations where documented declines have

562 been tied to acid deposition (DeHayes 1992; Schaberg et al. 2006). While growth of

563 sugar maple and red spruce, aside from low elevation, did display negative correlations

564 with S deposition, these relationships were not significant. One possible reason for this

565 outcome is the absence of long-term $\mathrm{S}$ and $\mathrm{N}$ deposition data. Datasets in this region only

566 span from 1965-2012, which excludes over a decade of acid deposition inputs. In

567 addition, detrending growth data with a flexible spline removes high frequency variation

568 and biological trends while preserving decadal and longer trends. Nevertheless, a

569 smoothing spline is one of the best options for reducing the effects of tree competition

570 and age-related growth trends. Lastly, relating growth to annual deposition data may

571 overlook more complex impacts of pollutant loading, such as long-term cumulative Ca

572 depletion. For example, research has shown that red spruce growth was related to the

573 historic accumulation of acidic inputs relative to the capacity of the site to buffer these

574 inputs (Engle et al. 2016).

575 Atmospheric $\mathrm{CO}_{2}$ concentration trends were not associated with growth (or

576 residuals of growth-climate models after accounting for the effects of climate) for any of

577 the species or elevations. Our findings align with others who have shown no significant

578 effect of elevated $\mathrm{CO}_{2}$ concentration on stem growth (e.g., Bader et al. 2013; Girardian et

579 al. 2016; Körner et al. 2005). While it is currently debated if elevated $\mathrm{CO}_{2}$ concentrations

580 will provoke changes in tree growth, there is evidence that $\mathrm{CO}_{2}$ effects are muted or 
581 nonexistent on sites where other environmental factors, including soil fertility

582 (particularly N-limitation) (Oren et al. 2001), temperature, and water (Körner et al. 2005),

583 are more limiting to stem growth than C (Körner 2003; Silva et al. 2013). Based on the

584 strong associations with growth of trees in this study and measures of heat that we

585 reported here, we hypothesize that temperature is more limiting to these trees than C

586 availability.

588 Conclusions

589 We presented a comparison of growth trends for five key tree species. While this

590 is a case study, by comparing the chronologies developed at this site to others in the

591 region, we show that at least for red spruce, there is strong alignment to the broader

592 region and propose that patterns evident here may be indicative of the region's forested

593 ecosystems. Comparisons of the chronologies (Fig. 2) highlight that the five species often

594 experienced changes in growth that were either species- or elevation-specific. There was

595 a high degree of year-to-year variability in growth, likely due to local abiotic and biotic

596 factors. For some species, the repeated stress of abiotic and biotic factors in succession

597 may help explain prolonged growth declines.

598 For most species and elevations, there was a positive association between higher

599 temperatures and growth during that same year, suggesting that contemporary warming

600 has improved the competitive status of many trees. However, there are two noted

601 exceptions to this trend. The first is that excessive heat (cumulative temperatures $>$

$60218.3^{\circ} \mathrm{C}$ ) the previous year was broadly associated with lower growth the following year.

603 Further investigation is needed to understand the complex interplay of elevated 
604 temperature and net growth in successive years and over time. The second exception is

605 that sugar maple trees at low elevation showed no positive association with increased

606 warming. This may provide field-based evidence of the sensitivity of sugar maple to the

607 warming that has been projected by climate change range models (e.g., Iverson et al.

608 2008).

609 Declines of red spruce have also been well documented, but the recent and

610 surprising growth surge had not been investigated. Here we show that it occurred across

611 elevations and watersheds and that perhaps another species, red maple, has had a

612 synchronous increase in growth. Both species show positive correlations with growing

613 season temperatures, including CDD. Indeed, CDD was consistently associated with

614 increased growth for most of species and elevations overall. This finding highlights the

615 potential value of CDD as an integrated temperature index with relevance to tree growth

616 in a warming world. While CDD was often positively associated with growth, pCDD

617 often had a negative relationship. As CDD increases in the future, its influence on tree

618 growth could be mixed. Results of this analysis suggest that some tree species may be

619 responding favorably to changing environmental conditions, while others are either

620 declining or appear stable in growth. Though this specific study covered a small spatial

621 scale, it opens avenues for future work to examine more fully some of the patterns that

622 emerged here. Indeed, there have been relatively few studies that have examined growth

623 trends and responses to the environment among species in the region; yet, this is of

624 interest as the climate changes and the future state of forest health and productivity

625 remains uncertain.

626 


\section{Acknowledgments}

628 We value the helpful manuscript edits from Drs. Andrea Lini (University of

629 Vermont, UVM) E. Carol Adair (UVM), Neil Pederson (Harvard Forest), and two

630 anonymous reviewers. We greatly appreciate the assistance in the field and laboratory by

631 Ben Engel, Dan Hale, Josh Halman, Kindle Loomis, Allyson Makuch, Jill Spies, and

632 Sam Wallace. Thanks to Chris Hansen, Ben Engel, and Aiko Weverka for sharing data.

633 Thanks are also extended to Jim Duncan and Carl Waite (Vermont Monitoring

634 Cooperative) for their assistance and approval of field collection. We also appreciate the

635 cooperation of the Vermont Department of Forest, Parks, and Recreation for providing

636 timely permission for field sampling. This manuscript is a contribution of the Hubbard

637 Brook Ecosystem Study. Hubbard Brook is part of the Long-Term Ecological Research

638 (LTER) network, which is supported by the National Science Foundation. The Hubbard

639 Brook Experimental Forest is operated and maintained by the USDA Forest Service,

640 Newtown Square, PA. This research was supported, in part, by the Forest Service

641 Northern Research Station and by grants from the Vermont Monitoring Cooperative and

642 USDA McIntire-Stennis Forest Research Program.

643

\section{References}

Aber, J., McDowell, W., Nadelhoffer, K., Alison, M., Berntson, G., Kamakea, M., McNulty, S., Currie, W., Rustad, L., and Fernandez, I. 1998. Nitrogen saturation in temperate forest ecosystems. BioSci 48(11): 921-934.

Abrams, M.D. 1998. The red maple paradox. BioSc 48(5): 355-364. 
Bader, M.K.F., Leuzinger, S., Keel, S.G., Siegwolf, R.T.W., Hagedorn, F., Schleppi, P., and Körner, C. 2013. Central European hardwood trees in a high- $\mathrm{CO}_{2}$ future: synthesis of an 8-year forest canopy $\mathrm{CO}_{2}$ enrichment project. J Ecol 101(6): 15091519. doi: 10.1111/1365-2745.12149.

Beckage, B., Osborne, B., Gavin, D.G., Pucko, C., Siccama, T., and Perkins, T. 2008. A rapid upward shift of a forest ecotone during 40 years of warming in the Green Mountains of Vermont. P Natl Acad Sci 105(11): 4197-4202. doi: 10.1073/pnas.0708921105.

Bishop, D.A., Beier, C.M., Pederson, N., Lawrence, G.B., Stella, J.C., and Sullivan, T.J. 2015. Regional growth decline of sugar maple (Acer saccharum) and its potential causes. Ecosphere 6(10): art179. doi: 10.1890/ES15-00260.1.

Bunn, A., Korpela, M., Biondi, F., Campelo, F., Merian, P., Qeadan, F., and Zang, C. 2015. dplR: Dendrochronology Program Library in R. R package version 1.6.3. http://r-forge.r-project.org/projects/dplr/.

Burns, D., Lynch, J., Cosby, B., Fenn, M., and Baron, J. 2011. National acid precipitation assessment program report to Congress 2011: an integrated assessment. U.S. Environmental Protection Agency, Washington, DC, USA.

Burns, R., and Honkala, B. 1990. Silvics of North America: 1. Conifers; 2. Hardwoods Agriculture Handbook 654. US Department of Agriculture, Forest Service, Washington, DC.

Cogbill, C.V. 1996. Historical ecology of the upper Stevensville Brook watershed, Underhill, Vermont. For Vermont Department of Forest, Parks and Recreation and Vermont Monitoring Cooperative. 
Cook, E.R., Johnson, A.H., and Blasing, T.J. 1987. Forest decline: modeling the effect of climate in tree rings. Tree Phys 3(1): 27-40. doi: 10.1093/treephys/3.1.27.

Cook, E.R., and Kairiukstis, L.A. (eds). 1990. Methods of Dendrochronology: Applications in the Envrionmental Sciences. Kluwer Academic Publishers, Dordrecht.

DeHayes, D.H. 1992. Winter injury and developmental cold tolerance of red spruce. In The Ecology and Decline of Red Spruce in the Eastern United States. Edited by C. Eagar and M.B. Adams. Springer-Verlag New York Inc., New York, NY, USA. pp. $295-337$.

DeHayes, D.H., Schaberg, P.G., Hawley, G.J., and Strimbeck, G.R. 1999. Acid rain impacts on calcium nutrition and forest health. BioSci 49(10): 789-800.

DeHayes, D.H., Schaberg, P.G., and Strimbeck, G.R. 2001. Red spruce cold hardiness and freezing injury susceptibility. In Conifer Cold Hardiness. Edited by F. Bigras. Kluwer Academic Publishers, Dordrecht, the Netherlands. pp. 495-529.

Duchesne, L., Ouimet, R., and Morneau, C. 2003. Assessment of sugar maple health based on basal area growth pattern. Can J Forest Res 33(11): 2074-2080. doi: 10.1139/x03-141.

Dupigny-Giroux, L.-A. 2002. Climate variability and socioeconomic consequences of Vermont's natural hazards: a historical perspective. Vermont History 70: 19-39. Engel, B.J., Schaberg, P.G., Hawley, G.J., Rayback, S.A., Pontius, J., Kosiba, A.M., and Miller, E.K. 2016. Assessing relationships between red spruce radial growth and pollution critical load exceedence values. Forest Ecol Manag 359: 83-91. 
Foster, J.R., and D'Amato, A.W. 2015. Montane forest ecotones moved downslope in northeastern U.S. in spite of warming between 1984 and 2011. Global Change Biol 21(12): 4497-4507. doi: 10.1111/gcb.13046.

Gavin, D.G., and Peart, D.R. 1993. Effects of beech bark disease on the growth of American beech (Fagus grandifolia). Can J Forest Res 23(8): 1566-1575. doi: $10.1139 /$ x93-197.

Girardin, M.P., Bouriaud, O., Hogg, E.H., Kurz, W., Zimmermann, N.E., Metsaranta, J.M., de Jong, R., Frank, D.C., Esper, J., Büntgen, U., Guo, X.J., and Bhatti, J. 2016. No growth stimulation of Canada's boreal forest under half-century of combined warming and $\mathrm{CO}_{2}$ fertilization. P Natl Acad Sci 113(52): E8406-E8414. doi: $10.1073 /$ pnas.1610156113.

Greaver, T.L., Sullivan, T.J., Herrick, J.D., Barber, M.C., Baron, J.S., Cosby, B.J., Deerhake, M.E., Dennis, R.L., Dubois, J.-J.B., Goodale, C.L., Herlihy, A.T., Lawrence, G.B., Liu, L., Lynch, J.A., and Novak, K.J. 2012. Ecological effects of nitrogen and sulfur air pollution in the US: what do we know? Front Ecol Environ 10(7): 365-372. doi: 10.1890/110049.

Hansen, C.F. 2015. LiDAR remote sensing of forest canopy structure and integrity: Trophic interactions among forest health, productivity, insects and birds. M.Sc. thesis, Rubenstein School of Envrionment and Natural Resoruces, University of Vermont, VT, USA.

Holmes, R.L. 1983. Computer-assisted quality control in tree-ring dating and measurment. Tree-ring Bull 43: 69-78. 
Hornbeck, J.W., Smith, R.B., and Federer, C.A. 1987. Growth decline in red spruce and balsam fir relative to natural processes. Water Air Soil Poll 31(1-2): 425-430. doi: 10.1007/BF00630860.

Hornbeck, J.W., and Smith, R.L. 1985. Documentation of red spruce growth decline. Canadian Journal of Forest Research 15: 1199-1201.

Hufkens, K., Friedl, M.A., Keenan, T.F., Sonnentag, O., Bailey, A., O'Keefe, J., and Richardson, A.D. 2012. Ecological impacts of a widespread frost event following early spring leaf-out. Global Change Biol 18(7): 2365-2377. doi: 10.1111/j.13652486.2012.02712.x.

Iverson, L.R., Prasad, A.M., Matthews, S.N., and Peters, M. 2008. Estimating potential habitat for 134 eastern U.S. tree species under six climate scenarios. Forest Ecol Manag 254(3): 390-406.

Johnson, A., Cook, E., and Siccama, T. 1988. Climate and red spruce growth and decline in the northern Appalachians. P Natl A Sci 85(15): 5369-5373.

Johnson, A.H., Friedland, A.J., and Dushoff, J.G. 1986. Recent and historic red spruce mortality: Evidence of climatic influencee. Water Air Soil Poll 30(1): 319-330. doi: $10.1007 / \mathrm{bf00305203.}$

Johnson, A.H., and Siccama, T.G. 1983. Acid deposition and forest decline. Envir Sci Tech 17(7): 294A-305A. doi: 10.1021/es00113a001.

Körner, C. 2003. Carbon limitation in trees. J Ecol 91(1): 4-17. doi: 10.1046/j.13652745.2003.00742.x. 
Körner, C., Asshoff, R., Bignucolo, O., Hättenschwiler, S., Keel, S.G., Peláez-Riedl, S., Pepin, S., Siegwolf, R.T., and Zotz, G. 2005. Carbon flux and growth in mature deciduous forest trees exposed to elevated $\mathrm{CO}_{2}$. Science 309(5739): 1360-1362.

Kosiba, A.M., Schaberg, P.G., Hawley, G.J., and Hansen, C.F. 2013. Quantifying the legacy of foliar winter injury on woody aboveground carbon sequestration of red spruce trees. Forest Ecol Manag 302: 363-371.

Kunkel, K.E., Stevens, L., Stevens, S., Sun, L., Janssen, E., Wuebbles, D., Rennells, J., DeGaetano, A., and Dobson, J. 2013. NOAA Technical Report NESDIS.

Regional climate trends and scenarios for the U.S. National Climate Assessment. Part 1: Climate of the Northeast U.S.

Lazarus, B.E., Schaberg, P.G., DeHayes, D.H., and Hawley, G.J. 2004. Severe red spruce winter injury in 2003 creates unusual ecological event in the northeastern United States. Can J Forest Res 34(8): 1784-1788.

LeBlanc, D.C. 1992. Spatial and temporal variation in the prevalence of growth decline in red spruce populations of the northeastern United States. Can. J. For. Res. 22: 1351-1363.

Likens, G. 2010. Chemistry of Steamwater at HBEF WS-1. Available from http://www.hubbardbrook.org/data/dataset.php?id=3 [acessed 14 October 2014].

Long, R.P., Horsley, S.B., Hallett, R.A., and Bailey, S.W. 2009. Sugar maple growth in relation to nutrition and stress in the northeastern United States. Ecol Appl 19(6): 1454-1466. doi: 10.1890/08-1535.1.

McLaughlin, S.B., Downing, D.J., Blasing, T.J., Cook, E.R., and Adams, H.S. 1987. An analysis of climate and competition as contributors to decline of red spruce in 
high elevation Appalachian forests of the eastern United States. Oecologia 72(4): 487-501. doi: 10.1007/BF00378973.

Minocha, R., Long, S., Thangavel, P., Minocha, S.C., Eagar, C., and Driscoll, C.T. 2010. Elevation dependent sensitivity of northern hardwoods to Ca addition at Hubbard Brook Experimental Forest, N.H., U.S.A. Forest Ecol and Manag 260(12): 21152124. doi: http://dx.doi.org/10.1016/j.foreco.2010.09.002.

National Atmospheric Deposition Program. 2014. NADP/NTN Monitoring Location VT99. U.S. Geological Survey. Available from http://nadp.sws.uiuc.edu/sites/siteinfo.asp?id=VT99\&net=NTN [accessed 10 May 2014].

National Drought Mitigation Center. 2014. Drought Risk Atlas. Available from http://droughtatlas.unl.edu/Data.aspx [accessed 10 October 2013].

NOAA Earth System Research Laboratory Global Monitoring Division. 2013. Monthly Average Mauna Loa $\mathrm{CO}_{2}$. Available from http://www.esrl.noaa.gov/gmd/ccgg/trends/ [accessed 6 October 2013].

NOAA National Weather Serivce. 2014. Monthly total growing degree days for Burlington, VT. Available from http://www.weather.gov/btv/climo_gdd [accessed 23 April 2014].

Ollinger, S.V., Aber, J.D., Lovett, G.M., Millham, S.E., Lathrop, R.G., and Ellis, J.M. 1993. A spatial model of atmospheric deposition for the northeastern U.S. Ecol Appl 3(3): 459-472.

Oren, R., Ellsworth, D.S., Johnsen, K.H., Phillips, N., Ewers, B.E., Maier, C., Schäfer, K.V., McCarthy, H., Hendrey, G., and McNulty, S.G. 2001. Soil fertility limits 
carbon sequestration by forest ecosystems in a $\mathrm{CO}_{2}$-enriched atmosphere. Nature 411(6836): 469-472.

Pederson, N., Bell, A.R., Cook, E.R., Lall, U., Devineni, N., Seager, R., Eggleston, K., and Vranes, K.J. 2013. Is an epic pluvial masking the water insecurity of the greater New York City region? J Climate 24(6): 1339-1354. doi: 10.1175/jcli-d$11-00723.1$

PRISM Climate Group. 2004. Available from http://prism.oregonstate.edu/ [accessed 10 May 2014].

R Development Core Team. 2015. R: A language and environment for statistical computing. R Foundation for Statistical Computing, Vienna, Austria.

Rennenberg, H., Loreto, F., Polle, A., Brilli, F., Fares, S., Beniwal, R., and Gessler, A. 2006. Physiological responses of forest trees to heat and drought. Plant Biol 8(05): 556-571.

Rhoads, A.G., Hamburg, S.P., Fahey, T.J., Siccama, T.G., Hane, E.N., Battles, J., Cogbill, C., Randall, J., and Wilson, G. 2002. Effects of an intense ice storm on the structure of a northern hardwood forest. Can J Forest Res 32(10): 1763-1775. doi: $10.1139 / \mathrm{x} 02-089$.

Salzer, M.W., Hughes, M.K., Bunn, A.G., and Kipfmueller, K.F. 2009. Recent unprecedented tree-ring growth in bristlecone pine at the highest elevations and possible causes. Proceedings of the National Academy of Sciences 106(48): 20348-20353. doi: 10.1073/pnas.0903029106.

Schaberg, P.G., and DeHayes, D.H. 2000. Physiological and envrionmental causes of freezing injury to red spruce. In Responses of Northern U.S. Forests to 
Environmental Change. Edited by R.A. Mickler and R.A. Birdsey and J.L. Hom. Springer-Verlag, New York. pp. 181-227.

Schaberg, P.G., Tilley, J.W., Hawley, G.J., DeHayes, D.H., and Bailey, S.W. 2006.

Associations of calcium and aluminum with the growth and health of sugar maple trees in Vermont. Forest Ecol Manag 223(1-3): 159-169. doi:

http://dx.doi.org/10.1016/j.foreco.2005.10.067.

Siccama, T.G. 1971. Presettlement and present forest vegetation in northern Vermont with special reference to Chittenden County. Am Midl Nat 85(1): 153-172.

Silva, L.C.R., and Anand, M. 2013. Probing for the influence of atmospheric $\mathrm{CO}_{2}$ and climate change on forest ecosystems across biomes. Global Ecology and Biogeography 22(1): 83-92. doi: 10.1111/j.1466-8238.2012.00783.x.

Silva, L.C.R., Anand, M., and Leithead, M.D. 2010. Recent widespread tree growth decline despite increasing atmospheric $\mathrm{CO}_{2}$. PLoS ONE 5(7): e11543. doi: 10.1371/journal.pone.0011543.

Soil Survey Staff. 2015. Natural Resources Conservation Service, United States Department of Agriculture. Web Soil Survey. Available from http://websoilsurvey.nrcs.usda.gov/ [accessed 15 August 2015].

Soule, P.T., and Knapp, P.A. 2006. Radial growth rate increases in naturally occurring ponderosa pine trees: a late-20th century $\mathrm{CO}_{2}$ fertilization effect? New Phytol 171(2): 379-390. doi: 10.1111/j.1469-8137.2006.01746.x.

Speer, J.H. 2010. Fundamentals of tree-ring research. University of Arizona Press. Stokes, M., and Smiley, T. 1968. An Introduction to Tree-Ring Dating. University of Chicago Press. 
The National Drought Mitigation Center. 2012. SPEI. University of Nebraska, Lincoln. Available from http://droughtatlas.unl.edu/About.aspx [acessed 15 March 2015]. van Doorn, N.S., Battles, J.J., Fahey, T.J., Siccama, T.G., and Schwarz, P.A. 2011. Links between biomass and tree demography in a northern hardwood forest: a decade of stability and change in Hubbard Brook Valley, New Hampshire. Can J Forest Res 41(7): 1369-1379. doi: 10.1139/x11-063.

Vermont Agency of Natural Resources Department of Forest Parks \& Recreation. 2010. Forest insects and disease conditions in Vermont 2010. Waterbury, VT.

Vermont Agency of Natural Resources Department of Forest Parks \& Recreation. 2013. Combined Master Dataset of Aerial Defoliation Surveys, 1985 to 2013. Hosted by Vermont Monitoring Cooperative. Available from http://www.uvm.edu/vmc/research/data.php?id=66] [accessed 25 July 2014].

Waterhouse, J.S., Switsur, V.R., Barker, A.C., Carter, A.H.C., Hemming, D.L., Loader, N.J., and Robertson, I. 2004. Northern European trees show a progressively diminishing response to increasing atmospheric carbon dioxide concentrations. Quaternary Sci Rev 23(7-8): 803-810. doi.org/10.1016/j.quascirev.2003.06.011.

West, P.W. 1980. Use of diameter increment and basal area increment in tree growth studies. Can J Forest Res 10(1): 71-77. doi:10.1139/x80-012.

Weverka, A.S. 2012. Remote sensing of productivity in northeastern forests. M.Sc. thesis, Rubenstein School of Envrionment and Natural Resources, University of Vermont, V.T.

Whitney, G. 1994. From coastal wilderness to fruited plain: An environmental history of the eastern U.S. 1500 to present. Cambridge University, Cambridge, MA. 
World Data Center for Paleoclimatology and NOAA Paleoclimatology Program. Law Dome ice core data. Available from: ftp:/ftp.ncdc.noaa.gov/pub/data/paleo/icecore/antarctica/law/law2006.txt [accessed 10 October 2016].

Yamaguchi, D.K. 1991. A simple method for cross-dating increment cores from living trees. Can J Forest Res 21(3): 414-416. doi: 10.1139/x91-053.

Zang, C., and Biondi, F. 2015. treeclim: an R package for the numerical calibration of proxy-climate relationships. Ecography 38(4): 431-436. doi: 10.1111/ecog.01335.

Zhang, Y., Bergeron, Y., Zhao, X.-H., and Drobyshev, I. 2015. Stand history is more important than climate in controlling red maple (Acer rubrum L.) growth at its northern distribution limit in western Quebec, Canada. J Plant Ecol 8(4): 368-379. doi: $10.1093 /$ jpe/rtu029. 
Table 1: Significant correlations from stationary climate-growth assessments for all species combined per elevation for trees from Mt. Mansfield, VT, as evaluated using Principal Component analysis (1925-2012). Significance based on $99 \%$ CI.

\begin{tabular}{|c|c|c|c|c|}
\hline \multirow[b]{2}{*}{ Elevation $^{a}$} & \multicolumn{2}{|c|}{ Positive } & \multicolumn{2}{|c|}{ Negative } \\
\hline & Variable $^{b, c}$ & $\begin{array}{l}\text { Cor. } \\
\text { Coef. }\end{array}$ & Variable $^{b}$ & $\begin{array}{l}\text { Cor. } \\
\text { Coef. }\end{array}$ \\
\hline \multirow{8}{*}{ High } & Water year $T_{\text {mean }}$ & 0.34 & HDD & -0.38 \\
\hline & $\mathrm{pWinter} \mathrm{T}_{\max }$ & 0.25 & & \\
\hline & $\mathrm{pFall} \mathrm{T}_{\min }$ & 0.40 & & \\
\hline & Winter $\mathrm{T}_{\text {mean }}$ & 0.26 & & \\
\hline & Spring $\mathrm{T}_{\text {mean }}$ & 0.27 & & \\
\hline & CDD & 0.37 & & \\
\hline & GDD & 0.39 & & \\
\hline & PDSI & 0.36 & & \\
\hline \multirow{6}{*}{ Mid } & Summer $\mathrm{T}_{\text {mean }}$ & 0.33 & & \\
\hline & May-June $\mathrm{T}_{\text {mean }}$ & 0.32 & & \\
\hline & Jun-Sep $\mathrm{T}_{\text {mean }}$ & 0.36 & & \\
\hline & CDD & 0.34 & & \\
\hline & pFeb SPEI & 0.43 & & \\
\hline & pDec SPEI & 0.38 & & \\
\hline \multirow{5}{*}{ Low } & pSpring $T_{\max }$ & 0.25 & Mar SPEI & -0.27 \\
\hline & Summer $\mathrm{T}_{\text {mean }}$ & 0.38 & & \\
\hline & May-Aug $\mathrm{T}_{\text {mean }}$ & 0.28 & & \\
\hline & pMar SPEI & 0.28 & & \\
\hline & $\mathrm{NH}_{4}^{+}$ & 0.35 & & \\
\hline
\end{tabular}

${ }^{a}$ Low $=450-650 \mathrm{~m}$ a.s.1., $\mathrm{mid}=750-850 \mathrm{~m}$, and high $=900-1000 \mathrm{~m}$

${ }^{b} \mathrm{p}=$ previous year, $\mathrm{T}=$ temperature, $\mathrm{Min}=$ minimum, $\mathrm{GDD}=$ growing degree days $\left(\right.$ cumulative degrees $\left.>5^{\circ} \mathrm{C}\left[41^{\circ} \mathrm{F}\right]\right), \mathrm{HDD}=$ heating degree days (cumulative days $<18.3^{\circ} \mathrm{C}\left[65^{\circ} \mathrm{F}\right]$ ), $\mathrm{CDD}=$ cooling degree days (cumulative degrees $>18.3^{\circ} \mathrm{C}\left[65^{\circ} \mathrm{F}\right]$ ), $\mathrm{CDD}=$ cooling degree days (cumulative degrees $>18.3^{\circ} \mathrm{C}\left[65^{\circ} \mathrm{F}\right]$ ), SPEI = Standardized Precipitation-Evapotranspiration Index, Winter: previous December-February, Spring: March-May, Summer: June-August, Fall: September-November. For more information on variables see methods.

${ }^{c}$ Not all variables span the entire chronology (1925-2012, 1945-2012, or 1965-2012). See methods. 
Table 2: Correlations from stationary climate-growth assessments from Mt. Mansfield, VT, shown by species and elevation for the entire chronology (1925-2012) and by chronology quartile. Coefficients in bold text are significant at $99 \%$ CI.

\begin{tabular}{|c|c|c|c|c|c|c|c|}
\hline \multirow[b]{2}{*}{ Species } & \multirow[b]{2}{*}{ Elevation $^{a}$} & \multirow[b]{2}{*}{ Variable $^{b}$} & \multirow{2}{*}{$\begin{array}{c}\text { Overall } \\
1925- \\
2012^{c}\end{array}$} & \multicolumn{4}{|c|}{ Quartiles } \\
\hline & & & & $\begin{array}{c}1925- \\
1946 \\
\end{array}$ & $\begin{array}{c}1947- \\
1968 \\
\end{array}$ & $\begin{array}{c}1969- \\
1990 \\
\end{array}$ & $\begin{array}{l}1991- \\
2012 \\
\end{array}$ \\
\hline \multirow{4}{*}{ Balsam fir } & \multirow{4}{*}{ High } & $\mathrm{pFall} \mathrm{T}_{\min }$ & 0.38 & 0.29 & 0.48 & 0.44 & 0.30 \\
\hline & & Spring $T_{\text {min }}$ & 0.24 & 0.17 & 0.59 & 0.19 & 0.08 \\
\hline & & $\mathrm{pCDD}$ & -0.37 & & -0.47 & -0.17 & -0.88 \\
\hline & & pGDD & -0.31 & & -0.48 & 0.03 & -0.88 \\
\hline \multirow{4}{*}{ Red maple } & \multirow{4}{*}{ Low } & CDD & 0.39 & & 0.24 & 0.34 & 0.65 \\
\hline & & Summer $\mathrm{T}_{\text {mean }}$ & 0.30 & 0.37 & 0.22 & 0.31 & 0.55 \\
\hline & & Jun-Sep $T_{\text {mean }}$ & 0.26 & 0.43 & 0.28 & 0.26 & 0.43 \\
\hline & & $\mathrm{pCDD}$ & -0.34 & & -0.59 & -0.27 & -0.17 \\
\hline \multirow{29}{*}{ Red spruce } & \multirow{11}{*}{ Low } & Water year $\mathrm{T}_{\text {mean }}$ & 0.43 & 0.44 & 0.52 & 0.24 & 0.48 \\
\hline & & $\mathrm{pFall} \mathrm{T}_{\min }$ & 0.32 & 0.19 & 0.41 & 0.23 & 0.53 \\
\hline & & Winter $\mathrm{T}_{\text {mean }}$ & 0.26 & 0.14 & 0.39 & -0.04 & 0.52 \\
\hline & & Spring $\mathrm{T}_{\text {mean }}$ & 0.36 & 0.34 & 0.37 & 0.26 & 0.46 \\
\hline & & May-Aug $\mathrm{T}_{\text {mean }}$ & 0.28 & 0.27 & 0.29 & 0.16 & 0.37 \\
\hline & & Jun-Sep $\mathrm{T}_{\text {mean }}$ & 0.43 & 0.31 & 0.48 & 0.01 & 0.13 \\
\hline & & $\mathrm{pCDD}$ & -0.35 & & -0.40 & -0.31 & -0.39 \\
\hline & & HDD & -0.37 & & -0.46 & -0.05 & -0.50 \\
\hline & & GDD & 0.38 & & 0.46 & 0.21 & 0.37 \\
\hline & & PDSI & 0.36 & & 0.44 & -0.56 & 0.10 \\
\hline & & $\mathrm{pNO}_{3}^{-}$ & -0.37 & & -0.164 & -0.17 & -0.46 \\
\hline & \multirow{6}{*}{ Mid } & Water year $T_{\text {mean }}$ & 0.27 & 0.35 & 0.53 & 0.17 & 0.42 \\
\hline & & pWinter $T_{\max }$ & 0.27 & 0.38 & 0.55 & -0.19 & 0.37 \\
\hline & & Jun-Sep $T_{\text {mean }}$ & 0.26 & 0.29 & 0.49 & 0.12 & 0.17 \\
\hline & & $\mathrm{pCDD}$ & -0.41 & & -0.38 & -0.51 & -0.40 \\
\hline & & GDD & 0.34 & & 0.44 & 0.13 & 0.39 \\
\hline & & May SPEI & -0.30 & & -0.15 & -0.29 & -0.44 \\
\hline & \multirow{12}{*}{ High } & Water year $\mathrm{T}_{\text {mean }}$ & 0.36 & 0.28 & 0.47 & 0.27 & 0.41 \\
\hline & & $\mathrm{pWinter} \mathrm{T}_{\max }$ & 0.23 & 0.36 & 0.46 & -0.07 & 0.24 \\
\hline & & $\mathrm{pFall} \mathrm{T}_{\min }$ & 0.32 & 0.05 & 0.53 & -0.28 & 0.52 \\
\hline & & Winter $\mathrm{T}_{\text {mean }}$ & 0.26 & 0.16 & 0.22 & 0.13 & 0.41 \\
\hline & & Summer $T_{\max }$ & 0.27 & -0.03 & 0.31 & 0.38 & 0.45 \\
\hline & & Fall $\mathrm{T}_{\text {mean }}$ & 0.23 & 0.39 & 0.28 & 0.25 & 0.11 \\
\hline & & Jun-Sep $\mathrm{T}_{\text {mean }}$ & 0.31 & 0.06 & 0.55 & 0.48 & 0.41 \\
\hline & & May-Aug $\mathrm{T}_{\text {mean }}$ & 0.33 & 0.04 & 0.39 & 0.46 & 0.20 \\
\hline & & $\mathrm{pCDD}$ & -0.32 & & -0.44 & -0.29 & -0.37 \\
\hline & & $\mathrm{CDD}$ & 0.42 & & 0.36 & 0.43 & 0.50 \\
\hline & & HDD & -0.34 & & -0.45 & 0.07 & -0.44 \\
\hline & & GDD & 0.45 & & 0.50 & 0.30 & -0.49 \\
\hline \multirow{5}{*}{ Sugar maple } & Low & & $\mathrm{N} / \mathrm{S}$ & & & & \\
\hline & \multirow{4}{*}{ Mid } & pSummer $T_{\text {mean }}$ & -0.25 & -0.12 & -0.40 & -0.23 & -0.22 \\
\hline & & pSummer $T_{\max }$ & -0.27 & -0.25 & -0.38 & -0.28 & -0.09 \\
\hline & & Summer $\mathrm{T}_{\text {mean }}$ & 0.26 & 0.19 & 0.45 & 0.08 & 0.33 \\
\hline & & pCDD & -0.38 & & -0.55 & -0.29 & -0.23 \\
\hline Yellow birch & Mid & Summer $\mathrm{T}_{\text {mean }}$ & 0.29 & 0.37 & 0.29 & 0.29 & 0.29 \\
\hline
\end{tabular}

${ }^{a}$ Low $=450-650 \mathrm{~m}$ a.s. $1 ., \mathrm{mid}=750-850 \mathrm{~m}$, and high $=900-1000 \mathrm{~m}$

${ }^{b} \mathrm{p}=$ previous, $\mathrm{T}=$ temperature, Max $=$ maximum, Min $=$ minimum, PDSI $=$ Vermont Palmer Drought Severity Index, GDD $=$ growing degree days (cumulative degrees $>5^{\circ} \mathrm{C}\left[41^{\circ} \mathrm{F}\right]$ ), $\mathrm{HDD}=$ heating degree days (cumulative days $<18.3^{\circ} \mathrm{C}\left[65^{\circ} \mathrm{F}\right]$ ), $\mathrm{CDD}=$ cooling degree days (cumulative degrees $>18.3^{\circ} \mathrm{C}\left[65^{\circ} \mathrm{F}\right]$ ), $\mathrm{SPEI}=$ Vermont Standardized Precipitation-Evapotranspiration Index, Winter: previous December-February, Spring: March-May, Summer: June-August, Fall: September-November. For more information on variables see methods.

${ }^{c}$ Not all variables span the entire chronology (1925-2012, 1945-2012, or 1965-2012). See methods. 


\section{Figure captions}

Fig. 1: Map of plot locations in Mt. Mansfield State Forest, VT, USA, showing (A) three watershed transects, each with three plots located within low, mid, and high elevational zones, (B) species sampled per elevational band, and (C) study site location within the region.

Fig. 2: Biweight robust mean basal area increment $\left(B A I, \mathrm{~cm}^{2} \pm \mathrm{SD}\right.$ shown with grey bars) by (A) species and (B) elevation from 1925-2012. A non-parametric Kruskal-Wallis test, followed by Wilcoxon Each Pair test, using species, elevation, and year as factors was significant for the three factors $(P<0.001)$. Different letters following species and elevations categories denote significant differences overall $(P<0.001)$. The model was also significant for each of the four 21-year quartiles (1925-1946, 1947-1986, 1969-1990, 1991-2012; denoted with grey dashed line, $P<0.001$ ), for species and elevation, but year was only significant for the period 1925-1946 (BF: balsam fir, RM: red maple, RS: red spruce, SM: sugar maple, YB: yellow birch, L: low elevation [450-650 m a.s.1.], M: mid [750-800 m], and H: high [900-1000 m]). Bonferonni adjusted $P$-values were used.

Fig. 3: Mean basal area increment (BAI, $\mathrm{cm}^{2}$, solid black line) ( $\pm \mathrm{SD}$ ) chronologies per species and elevational zone: (A) low 450-650, (B) mid 750-800, and (C) high 900-1000 $\mathrm{m}$ a.s.l. elevation from 1925-2012 in Mt. Mansfield State Forest, VT. Number of trees contributing the mean are shown with grey bars. Red circles designate the five highest growth years per chronology.

Fig. 4: Comparisons of mean growth $(B A I \pm S D)$ for red spruce, sugar maple, and yellow birch from this study on Mt. Mansfield to (A) sugar maple and (B) yellow birch at Hubbard Brook Experimental Forest (HBEF), NH, and (C) red spruce in the region (34 plots in VT, NH, MA). Spearman correlation coefficients (R) and associated $P$-values are shown in each figure. Chronologies at HBEF were limited to 1950-2012. 


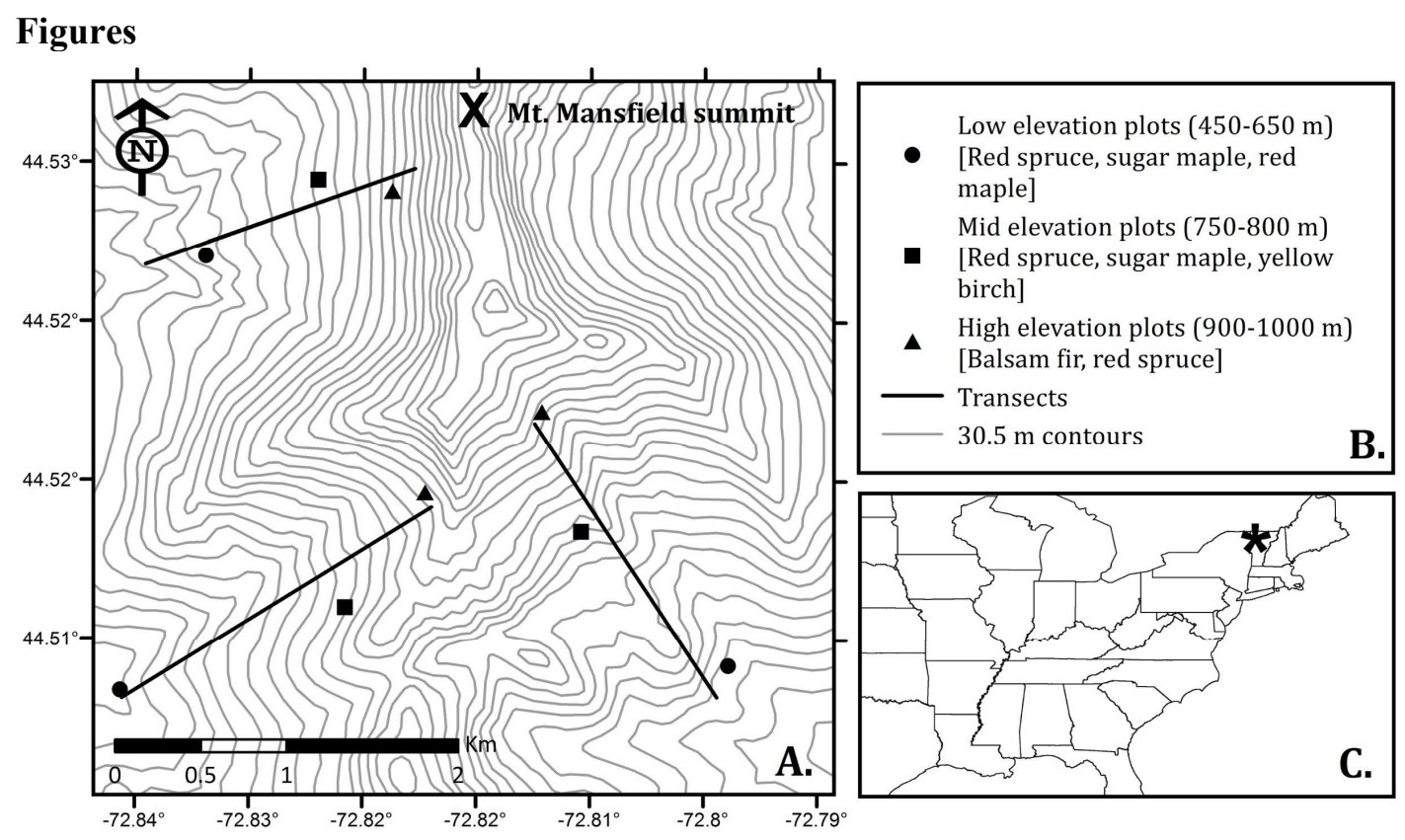

Fig. 1 


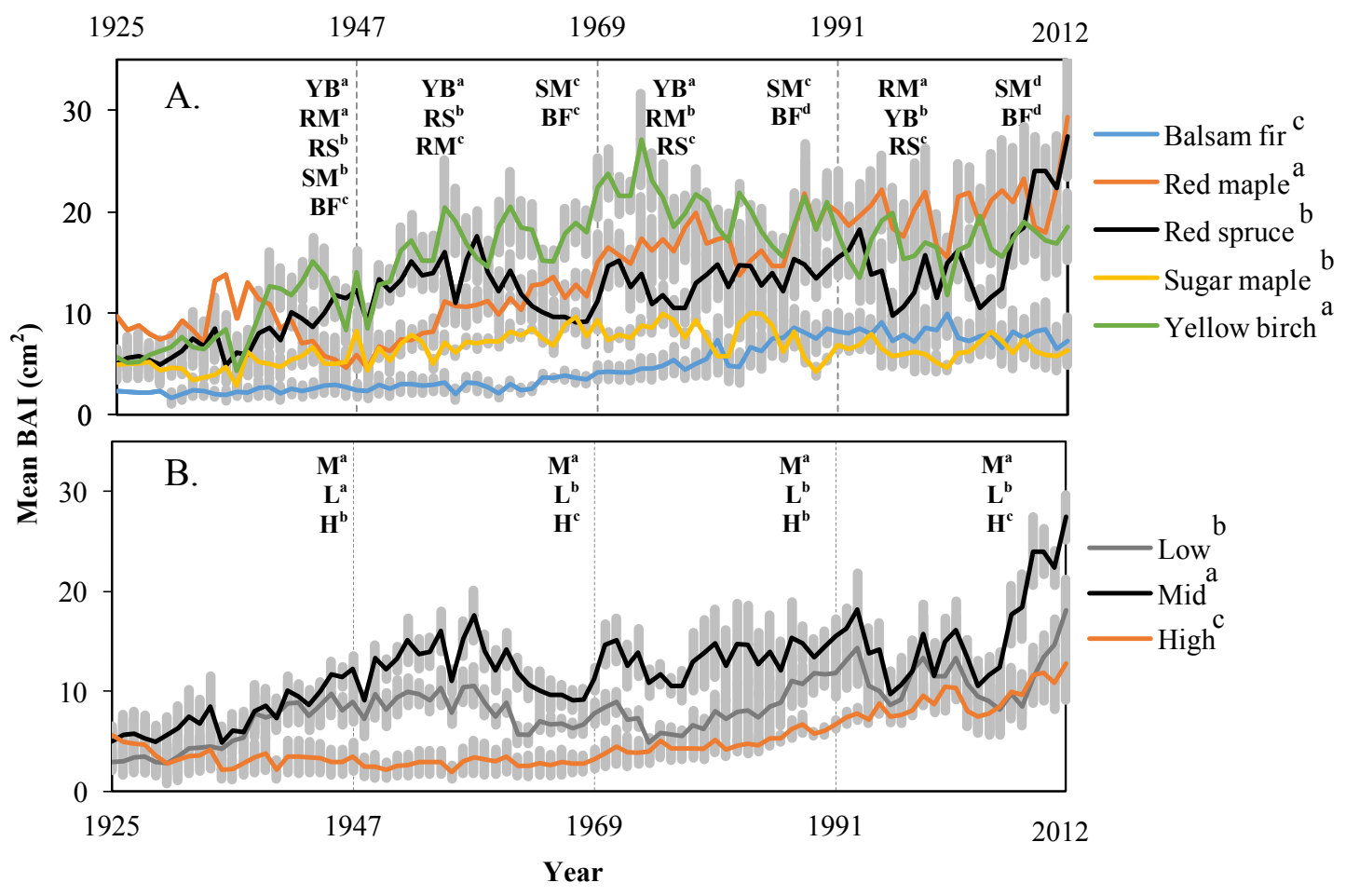

Fig. 2 
A. Low elevation
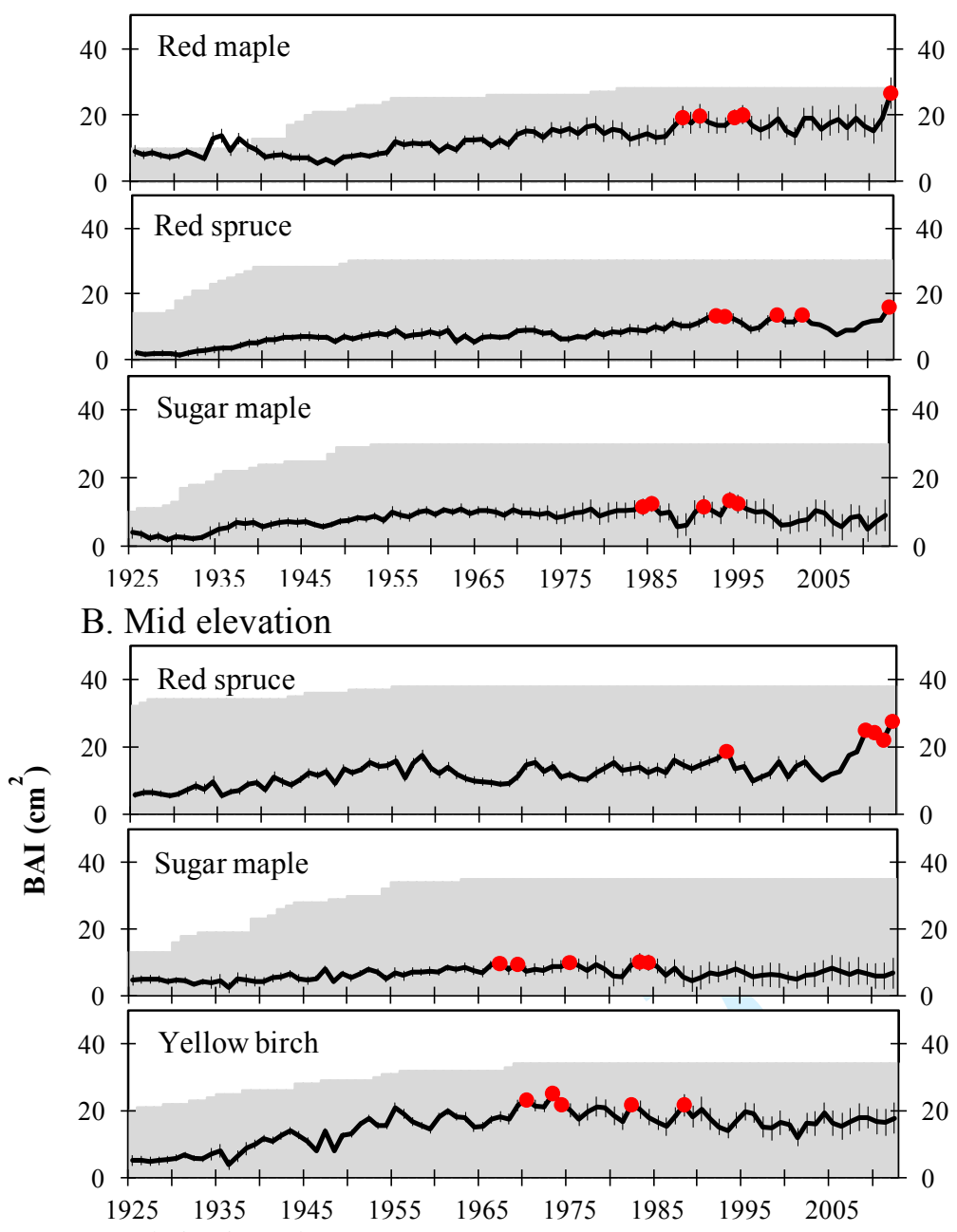

\section{苞}

C. High elevation

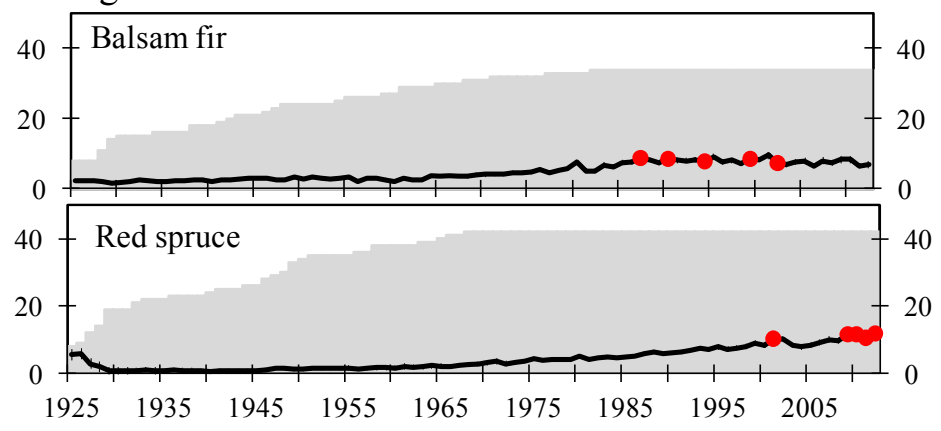

Year

Fig. 3 


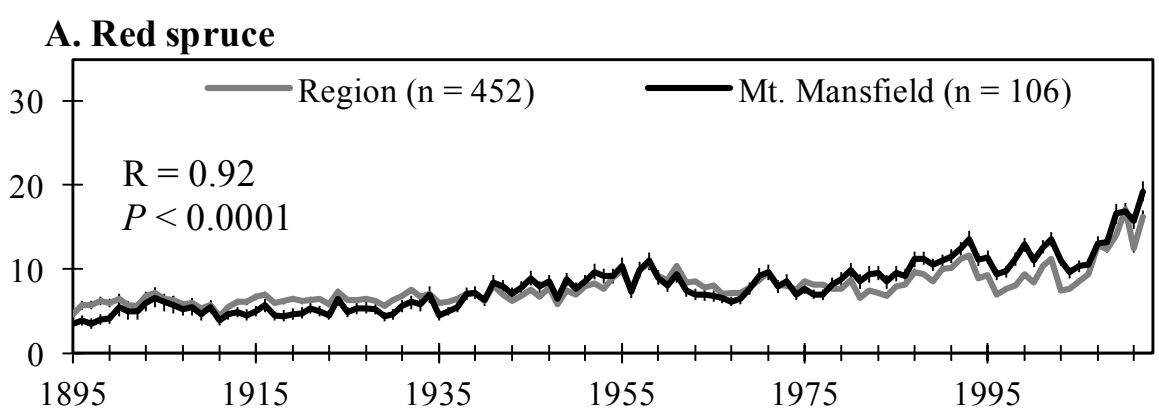

\section{B. Sugar maple}

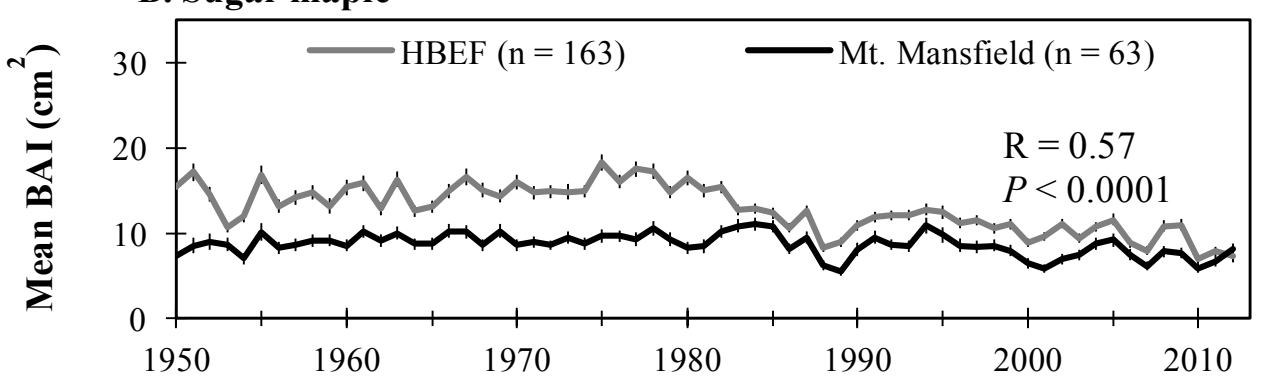

C. Yellow birch

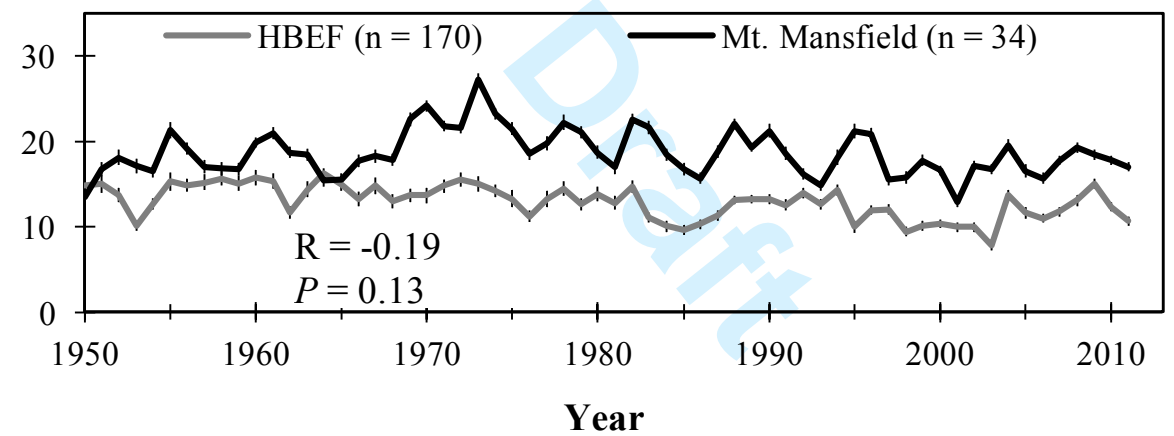

Fig. 4 


\section{Supplemental Materials}
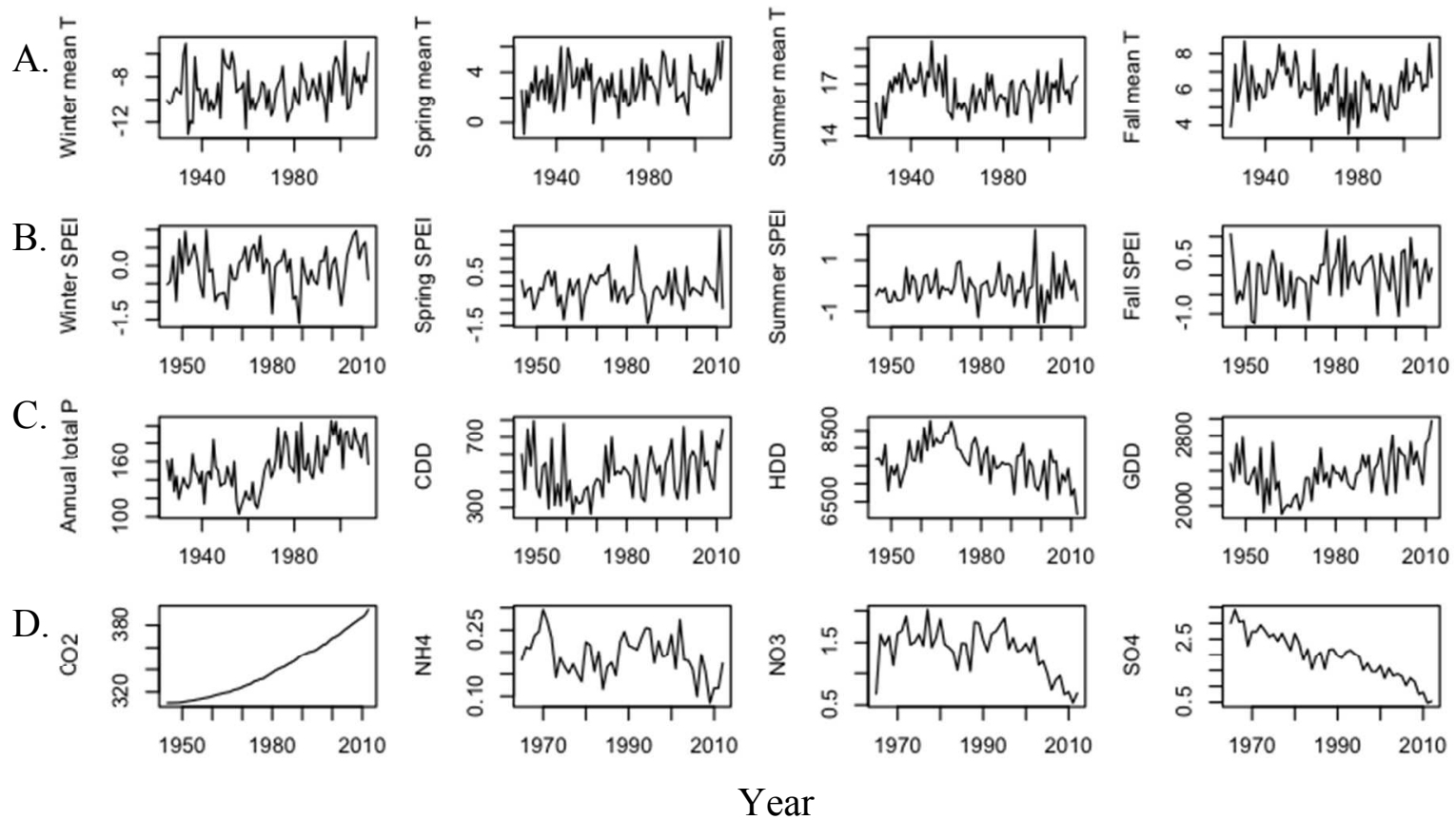

Fig. S1: (A) Mean seasonal (Winter [p Dec-Feb], Spring [Mar-May], Summer [Jun-Aug], and Fall [SepNov]) temperatures $\left({ }^{\circ} \mathrm{C} ; 1925-2012\right)$ for the study location (see Methods for more details). (B) Seasonal Standardized Precipitation-Evapotranspiration Index (SPEI; 1945-2012) for Vermont (VT). (C) Annual total precipitation $(\mathrm{cm})$ for the study location (1925-2012); cooling degree days (CDD, measured as degrees $\left.>18.3^{\circ} \mathrm{C}, 1945-2012\right)$, heating degree days $\left(\mathrm{HDD},<18.3^{\circ} \mathrm{C}, 1945-2012\right)$ and growing degree days (GDD, $>5^{\circ} \mathrm{C}, 1945-2012$ ) for VT. (D) Atmospheric $\mathrm{CO}_{2}$ concentration (ppm, 1945-2012) from Mauna Loa, HI; deposition $\left(1965-2012, \mathrm{mg} / \mathrm{L}\right.$, by water year) of ammonium $\left(\mathrm{NH}_{4}^{+}\right)$, nitrate $\left(\mathrm{NO}_{3}{ }^{-}\right)$, and sulfate $\left(\mathrm{SO}_{4}^{-}\right)$from Hubbard Brook Experimental Forest (Thorton, NH) and Mt. Mansfield (VT).

Table S1: Raw tree ring data and statistics listed by species per elevational zone across the three watersheds.

\begin{tabular}{|c|c|c|c|c|c|c|c|c|}
\hline Species & $\begin{array}{l}\text { Elev. } \\
\text { Zone }^{a}\end{array}$ & $\begin{array}{c}\mathrm{N} \\
\text { trees }\end{array}$ & $\begin{array}{l}\text { Mean DBH } \\
\quad \pm \mathrm{SD}^{b}\end{array}$ & $\begin{array}{c}\text { Age at } \mathrm{BH} \pm \\
\mathrm{SD}^{c}\end{array}$ & $\begin{array}{l}\text { Mean BAI } \\
\quad \pm \mathrm{SD}^{d}\end{array}$ & $\begin{array}{l}\text { Inter- } \\
\text { series } \\
\text { corr. }^{e}\end{array}$ & $\begin{array}{l}\text { Mean } \\
\text { Sens. }^{e}\end{array}$ & $\operatorname{Max} . \mathrm{BAI} \pm \mathrm{SD}^{\mathrm{f}}$ \\
\hline Balsam fir & High & 34 & $23.4 \pm 3.4$ & $77.9 \pm 20.4$ & $7.9 \pm 3.4$ & 0.583 & 0.209 & $10 \pm 2.2(2001)$ \\
\hline Red maple & Low & 28 & $39.6 \pm 8.4$ & $90.0 \pm 25.2$ & $19.6 \pm 11.2$ & 0.514 & 0.225 & $29.8 \pm 5.8(2012)$ \\
\hline \multirow{3}{*}{ Red spruce } & Low & 31 & $34 \pm 9.3$ & $142.7 \pm 55.8$ & $11.3 \pm 9.3$ & 0.519 & 0.257 & $18.1 \pm 3.4(2012)$ \\
\hline & Mid & 34 & $41.5 \pm 10.2$ & $165.5 \pm 51$ & $16.1 \pm 10.2$ & 0.559 & 0.254 & $27.9 \pm 4.0(2012)$ \\
\hline & High & 41 & $23.5 \pm 8.2$ & $86.7 \pm 32.8$ & $8.1 \pm 4.1$ & 0.579 & 0.236 & $13.2 \pm 3.4(2012)$ \\
\hline \multirow{2}{*}{ Sugar maple } & Low & 29 & $32.5 \pm 5.8$ & $95.9 \pm 20.3$ & $9.9 \pm 5.8$ & 0.474 & 0.304 & $14.2 \pm 1.1(1994)$ \\
\hline & Mid & 34 & $28.2 \pm 6.8$ & $93.1 \pm 23.8$ & $7 \pm 3.4$ & 0.466 & 0.325 & $10.5 \pm 2.3(1983)$ \\
\hline Yellow birch & Mid & 34 & $43.2 \pm 10.2$ & $101.1 \pm 27.2$ & $18 \pm 10.2$ & 0.467 & 0.286 & $22.7 \pm 0.6(1982)$ \\
\hline \multicolumn{9}{|c|}{$\begin{array}{l}{ }^{c} \text { Age in years is approximate, based on number of rings at breast height and distnace to pith. } \\
{ }^{d} \text { Mean basal area increment }\left(\mathrm{cm}^{2}\right) \text { calculated using the follwing formula } B A I=\pi\left(R_{n}^{2}-R_{n-1}^{2}\right) \text { (West 1980). } \\
{ }^{e} \text { Interseries correlation and mean sensitivity, from COFECHA output. }\end{array}$} \\
\hline
\end{tabular}


Table S2: Chronology statistics from Mt. Mansfield, VT, detrended with a 67\% cubic smoothing spline and prewhitened, computed for 30-year time periods with 15-year overlap from 1923-2012.

\begin{tabular}{|c|c|c|c|c|c|c|c|}
\hline \multirow[b]{2}{*}{ Species } & \multirow[b]{2}{*}{ Elevation $^{a}$} & \multirow[b]{2}{*}{$\mathrm{Stat}^{b}$} & \multicolumn{5}{|c|}{ Time period } \\
\hline & & & 1923-1952 & $1938-1967$ & 1953-1982 & 1968-1997 & 1983-2012 \\
\hline \multirow{5}{*}{ Balsam fir } & \multirow{5}{*}{ High } & $\mathrm{n}$ cores & 40 & 53 & 59 & 59 & 59 \\
\hline & & $\mathrm{n}$ trees & 24 & 30 & 34 & 34 & 34 \\
\hline & & Rbar & 0.22 & 0.44 & 0.38 & 0.30 & 0.31 \\
\hline & & EPS & 0.82 & 0.95 & 0.95 & 0.94 & 0.94 \\
\hline & & SNR & 4.67 & 18.83 & 18.68 & 14.52 & 15.26 \\
\hline \multirow{5}{*}{ Red maple } & \multirow{5}{*}{ Low } & $\mathrm{n}$ cores & 63 & 77 & 86 & 86 & 86 \\
\hline & & $\mathrm{n}$ trees & 39 & 46 & 51 & 51 & 51 \\
\hline & & Rbar & 0.15 & 0.21 & 0.16 & 0.13 & 0.08 \\
\hline & & EPS & 0.82 & 0.91 & 0.91 & 0.88 & 0.82 \\
\hline & & SNR & 4.57 & 10.06 & 8.55 & 7.11 & 4.69 \\
\hline \multirow{15}{*}{$\begin{array}{c}\text { Red } \\
\text { spruce }\end{array}$} & \multirow{5}{*}{ Low } & $\mathrm{n}$ cores & 54 & 56 & 56 & 56 & 56 \\
\hline & & $\mathrm{n}$ trees & 31 & 31 & 31 & 31 & 31 \\
\hline & & Rbar & 0.28 & 0.40 & 0.34 & 0.26 & 0.28 \\
\hline & & EPS & 0.91 & 0.95 & 0.94 & 0.92 & 0.93 \\
\hline & & SNR & 10.13 & 19.89 & 16.13 & 10.70 & 12.27 \\
\hline & \multirow{5}{*}{ Mid } & $\mathrm{n}$ cores & 74 & 78 & 78 & 78 & 78 \\
\hline & & $\mathrm{n}$ trees & 38 & 39 & 39 & 39 & 39 \\
\hline & & Rbar & 0.45 & 0.47 & 0.41 & 0.35 & 0.43 \\
\hline & & EPS & 0.97 & 0.97 & 0.96 & 0.96 & 0.97 \\
\hline & & SNR & 29.05 & 33.09 & 26.51 & 21.00 & 29.01 \\
\hline & \multirow{5}{*}{ High } & $\mathrm{n}$ cores & 60 & 72 & 78 & 78 & 78 \\
\hline & & $\mathrm{n}$ trees & 33 & 40 & 41 & 41 & 41 \\
\hline & & Rbar & 0.46 & 0.43 & 0.41 & 0.31 & 0.41 \\
\hline & & EPS & 0.95 & 0.96 & 0.96 & 0.95 & 0.97 \\
\hline & & SNR & 17.36 & 23.69 & 26.39 & 18.65 & 28.03 \\
\hline \multirow{10}{*}{$\begin{array}{l}\text { Sugar } \\
\text { maple }\end{array}$} & \multirow{5}{*}{ Low } & $n$ cores & 45 & 47 & 47 & 48 & 48 \\
\hline & & $\mathrm{n}$ trees & 30 & 31 & 31 & 31 & 31 \\
\hline & & Rbar & 0.16 & 0.12 & 0.13 & 0.22 & 0.34 \\
\hline & & EPS & 0.80 & 0.80 & 0.82 & 0.90 & 0.94 \\
\hline & & SNR & 3.90 & 3.97 & 4.39 & 8.55 & 15.89 \\
\hline & \multirow{5}{*}{ Mid } & n cores & 46 & 56 & 57 & 57 & 57 \\
\hline & & $\mathrm{n}$ trees & 29 & 34 & 34 & 34 & 34 \\
\hline & & Rbar & 0.30 & 0.25 & 0.26 & 0.24 & 0.19 \\
\hline & & EPS & 0.89 & 0.91 & 0.92 & 0.92 & 0.89 \\
\hline & & SNR & 8.44 & 9.51 & 11.64 & 10.82 & 8.20 \\
\hline \multirow{5}{*}{$\begin{array}{c}\text { Yellow } \\
\text { birch }\end{array}$} & \multirow{5}{*}{ Mid } & $n$ cores & 46 & 56 & 59 & 59 & 59 \\
\hline & & $\mathrm{n}$ trees & 29 & 32 & 34 & 34 & 34 \\
\hline & & Rbar & 0.26 & 0.25 & 0.16 & 0.22 & 0.20 \\
\hline & & EPS & 0.90 & 0.91 & 0.86 & 0.90 & 0.90 \\
\hline & & SNR & 8.74 & 9.59 & 6.14 & 9.45 & 8.65 \\
\hline
\end{tabular}

${ }^{a}$ Low $=450-650 \mathrm{~m}$ a.s.l., $\mathrm{mid}=750-850 \mathrm{~m}$, and high $=900-1000 \mathrm{~m}$

${ }^{b} \mathrm{R}$ bar $=$ Effective R bar, a weighted average of RBT (R bar betweenn trees) and RWT (R bar within trees) and thus a measure of correlation among and between cores, EPS = expressed population signal, $\mathrm{SNR}=$ signal to noise ratio. 